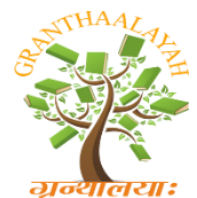

INTERNATIONAL JOURNAL OF RESEARCH GRANTHAALAYAH A knowledge Repository

Science

\title{
THEORETICAL STUDY OF THE POTENTIAL ANTI-CHAGASIC PHARMACOLOGICAL TOOL MACHILIN G: A STUDY OF MOLECULAR DOCKING
}

\author{
Victor da Silva de Almeida ${ }^{1}$, Victor Moreira de Oliveira ${ }^{1}$, Carlos Lacerda de Morais \\ Filho ${ }^{1}$, Francisco Rogênio da Silva Mendes ${ }^{1,2}$, Aluísio Marques da Fonseca ${ }^{3}$, Emmanuel \\ Silva Marinho *1 \\ ${ }^{*}$ Chemistry Department/FAFIDAM, State University of Ceará-Brazil \\ ${ }^{2}$ Northeast Biotechnology Network / RENORBIO, State University of Ceará-Brazil \\ ${ }^{3}$ Academic Master'sDegree in Sociobiodiversity and Sustainable Technologies, Universidade da \\ Integração Internacional e da Lusofonia Afro-Brasileira,-Brazil
}

\begin{abstract}
Chagas disease caused by Trypanosoma cruzi, which affects thousands of people around the world. In recent years, research aimed at the discovery of new drugs has started to seek specific macromolecular targets for the disease. In this context, enzymes are therapeutic targets of great interest, since they play a fundamental role in many diseases. In this context, the present work aimed to characterize the Machilin G molecule conformationally and evaluate its interactions in the main therapeutic targets involved in the replication of T. cruzi. To understand the inhibitory mechanism of Machilin $G$ on the evolutionary forms of $T$. cruzi, the molecule it was conformationally characterized, until reaching thermodynamic stability, and then it was submitted to molecule docking routines, having as protein targets the Cruzain enzymes, Tripanothione reductase and glyceraldehyde-3-phosphate dehydrogenase (TcGAPDH). Machilin G had its structure optimized using semi-empirical quantum calculations, through this technique it was possible to generate the thermodynamically more stable conformation. Through the method of analysis of the computer simulations of molecular anchoring, it was demonstrated that the ligand Machilin $G$ was coupled to the active site of the enzyme TcGAPDH, at distances close to the chalepin. In relation to Cruzain, it is possible to highlight that the ligand Machilin $G$ does not interact with the amino acids of the active site of the enzyme, being at a considerable distance in relation to the ligand KB2. Regarding the enzyme Trypanothione reductase, the ligand Machilin $\mathrm{G}$ had few interactions with the amino acids of the active site. The intermolecular interactions found for the complex formed and the values obtained at a distance from the enzyme residues indicate that Machilin $\mathrm{G}$ has potential application as a new inhibitor of the enzyme Trypanosoma cruzi TcGAPDH. The present work being a fundamental step for the understanding of Machilin $G$ mechanism of action in view of the evolutionary forms of the $\mathrm{t}$-cruzi parasite.
\end{abstract}

Keywords: Cruzain; Docking Molecular; Frontier Orbitals; Glyceraldehyde-3-Phosphate Dehydrogenase; Tripanothione Reductase. 
Cite This Article: Victor da Silva de Almeida, Victor Moreira de Oliveira, Carlos Lacerda de Morais Filho, Francisco Rogênio da Silva Mendes, Aluísio Marques da Fonseca, and Emmanuel Silva Marinho. (2020). "THEORETICAL STUDY OF THE POTENTIAL ANTI-CHAGASIC PHARMACOLOGICAL TOOL MACHILIN G: A STUDY OF MOLECULAR DOCKING." International Journal of Research - Granthaalayah, 8(2), 188-211. https://doi.org/10.5281/zenodo.3698202.

\section{Introduction}

Originally arising in rural areas of the Americas in the 20th century, Chagas disease caused by Trypanosoma cruzi, known as American trypanosomiasis, is a parasitic disease that affects thousands of people worldwide and is a neglected disease in the Americas (mainly in rural areas of Latin America, where poverty is widespread, however, in large numbers in urban areas, where about $60 \%$ of people are infected). Chagas disease is caused by infection by the protozoan parasite Trypanosoma cruzi (Tc) [1][2]. Due to increasing urbanization this disease has changed its progressive epidemiological pattern and has spread to other continents, becoming a public health problem, current estimates indicate that about 7 million people are infected with Trypanosoma cruzi worldwide, and mainly in the countries of continental Latin America, causing an additional 7000 deaths per year and exposing the risk of infection to more than 25 million people[3][4]. these data become more worrying, due to the loss of efficiency of benznidazole, the only drug currently recommended for the treatment of the disease, and which is associated with serious side effects. Therefore, it is necessary to identify new pharmacological targets for the selection of molecules with good efficacy against the parasite and low toxicity[5]. To combat this disease, several chemical therapeutic methods are tested in order to discover the most effective way to reduce the damage that Trypanosoma cruzi brings to health. The form of transmission to humans is mainly through the feces of triatomine insects, known in Brazil as "barbers", for the habit of stinging the faces of their victims. In recent years, research aimed at the discovery of new drugs has started to seek specific macromolecular targets for the disease. In this context, enzymes are crucial for the evolution of parasitic forms. Currently, the Cruzain enzymes, Tripanotiona reductase and Trypanosoma cruzi glyceraldehyde-3-phosphate dehydrogenase (TcGAPDH), are the main enzymes studied with targets and are therapeutic targets of great interest, since they play a fundamental role in many diseases[6]. In this search for potential pharmacological tools Machilin $\mathrm{G}$ showed antitrypanosomal activity, with an inhibitory concentration (IC50) of $2.2 \mu \mathrm{M}$ and potential antileishmanial activity, with a value of $50.54 \mu \mathrm{M}$, against $L$. donovani, indicating that it is a molecule that has potential for the development of antichagasic drugs [7][8][9].

Molecular modeling techniques have been promoting the understanding of the mechanisms of action of drugs, making it possible to characterize the molecules conformationally[10][11][12], as well as simulating the fit between the molecule and its potential therapeutic target (molecular docking)[13][14]. For the study of new compounds and their possible activities biological, it is essential to know the structure of the molecule in question, defining its thermodynamically more stable conformation, characterizing the surface behavior of the potential, identifying the possible electrophilic and nucleophilic sites[15][16]. In this context, molecular modeling uses in silico methods and theoretical calculations, which allow the characterization of molecular structures and their properties, in addition to predicting the mechanism of interaction between molecules and possible biological targets[14], [17][18] .In this context, the present work aimed to characterize 
the Machilin G molecule conformationally, and to evaluate its interactions in the main therapeutic targets involved in the replication of T-cruzi. The present work being a fundamental step for the understanding of Machilin $\mathrm{G}$ mechanism of action in view of the evolutionary forms of the $T$-cruzi parasite.

\section{Materials and Methods}

\subsection{Obtaining Protein Structures and Atomic Coordinates}

The protein structures studied in this work were obtained from RCSB protein da bank (https://www.rcsb.org/)[19] and the two-dimensional coordinates of the ligand in the PubChem repository[20], is an open chemistry database at the National Institutes of Health (https: //pubchem.ncbi.nlm.nih.gov/compound/Machilin-G).

\subsection{Structural Optimization}

The study of the Machiling G molecule was carried out using the quantum method at the semiempirical level Parametric Method 3 (PM3)[21], an algorithm that shows excellent correlation with experimental results and requires less computational resources than the traditional $\mathrm{Ab}$ initio method. For structural optimization and electronic characterization of the Machilin G molecule, it was performed using the semi-empirical quantum method Parametric Method 3 (PM3)[22], an algorithm that shows excellent correlation with experimental results and requires less computational resources than the traditional Ab initio method. The ArgusLab (tm) Version 4.0 software was used to support the execution of the PM3 code, configured so that the Hartree-Fock SCF performs 200 interactions with $10-10 \mathrm{kcal} / \mathrm{mol}$ closed-shell convergence[23]. Using the data generated from the optimization (file.out), it was possible to calculate the single point and determine the structural, electronic and reactivity properties. With the electronic characterization data it was possible to plot the potential surface map, and with the reactivity data to plot the Frontier orbitals[24].

\subsection{Enzyme Preparation}

The three-dimensional structures of the proteins Cruzain, Tripanotiona Redutase and TcGAPDH were obtained from the protein data bank database https://www.rcsb.org/structure/3iut, https://www.rcsb.org/structure/1k3t and https: //www.rcsb.org/structure/1gxf, Cruzain classified as protein hydrolase a structure crystallized in the complex with an inhibitor of tetrafluorophenoxymethyl ketone organism type Trypanosoma cruzi expression system type komagataella pastoris mutation (s): 2, method: x-ray diffraction, resolution: 1.2 å, r-value free: 0.153 , r-value work: 0.127 , deposited as 3iut[25]. The TcGAPDH protein structure of glycosomal glyceraldehyde-3-phosphate dehydrogenase from Trypanosoma cruzi complexed with Chalepin, the coumarin derivative inhibitor classified as oxidoreductase, organism (s): trypanosoma cruzi, expression system: escherichia coli experimental data snapshot method: x-ray diffraction resolution : 1.95 å r-value free: $0.280 \mathrm{r}$-value work: 0.201 deposited as $1 \mathrm{k} 3 \mathrm{t}$ [26]. Trypanothione reductase in complex with quinacrine mustard inhibitor classification: oxidoreductase organism (s): Trypanosoma cruzi expression system: escherichia coli experimental data snapshot method:

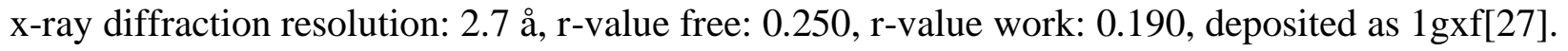


All water molecules were removed from protein structures, reducing interference with the binding of Machilin $\mathrm{G}$ to the target enzyme. Polar hydrogen atoms missing from the structure were added using AutoDock Tools. After that, the docking was carried out with each protein with residues using the Machilin $\mathrm{G}$ ligand as a comparison, and each open protein with residues had its specific ligand to be compared with the Machilin G (Cruzain-kb2) ligand (TcGAPDH-chapelin BRZ) ( Trypanothione reductase-quinacrine mustard QUM) in order to find the best result in the active site of the molecule, After choosing the best result saved the protein pdb and the ligand with the best rmsd and affinity, then each protein was opened without residues and with the best Docking was done between the amino acid residues and the protein and its respective ligand. And then with the help of Discovery, you can visualize the types of interactions formed[28].

\subsection{Molecular Docking}

Molecular attachment of the ligand to receptor was performed using 4-way multithreading and the AutoDock Tools (version 1.5.7) [29]graphical interface that runs AutoDock Vina (version 1.1.2)[30]. to carry out molecular docking, some protocols were used, such as delimiting the grid box of each protein, Cruzain protocol (pdb: 3iut) grid box center_x $=6,612$, center_y $=-0.436$, center_z $=8,052$, size_x $=116$, size_y $=106$, size_z $=126$, spacing $=0.431$ and exhaustiveness $=$ 8. TcGAPDH protocol (pdb: $1 \mathrm{k} 3 \mathrm{t}$ ) grid box center_x $=19.822$, center_y $=0.455$, center_z $=$ 24.804 , size_x $=116$, size_y $=112$, size_z $=122$, spacing $=0.931$ and exhaustiveness $=8$. Trypanothione reductase protocol (pdb: 1gxf) grid box center_x $=44.196$, center_y $=3.102$, center_z $=-0.054$, size_ $\mathrm{x}=126$, size_y $=90$, size_ $\mathrm{z}=126$, spacing $=0.775$ and exhaustiveness $=$ 8.The images of the two-dimensional graphs of the interactions and three-dimensional visualization of the complex formed were generated using the Discovery Studio visualizer® [31] and UCSF Chimera [[32]

\section{Results and Discussions}

The advances in information technologies have provided an increase in access to data, allowing quick access to structural and physical-chemical characteristics of several molecules. These repositories provide an incentive in the study of the characterization of several molecules, since they provide structural descriptors, which serve as initial inputs for further studies. In this perspective, the online virtual repository PubChem® [20]was used to obtain initial information about Machilin G acetate (PubChem CID: 10450921), as its official nomenclature by IUPAC (5 [(2S, 3S, 4R, 5R) -5- (3,4-dimethoxyphenyl) -3,4-dimethyloxolan-2-yl] -1,3-benzodioxole), molecular formula $(\mathrm{C} 21 \mathrm{H} 24 \mathrm{O} 5)$, molecular weight $(356.4 \mathrm{~g} / \mathrm{mol})$, exact mass $(356.162374 \mathrm{~g} /$ mol), XLogP3-AA (4.3), monoisotopic mass (356.162374 g / mol), polar topological surface area $\left(46.2 \AA^{2}\right.$ ). The two-dimensional coordinates show in their structure 5 hydrogen bonding donor atoms, 4 Rotatable Bond Count, and 4 Defined Atom Stereocenter Count and (figure 1). 

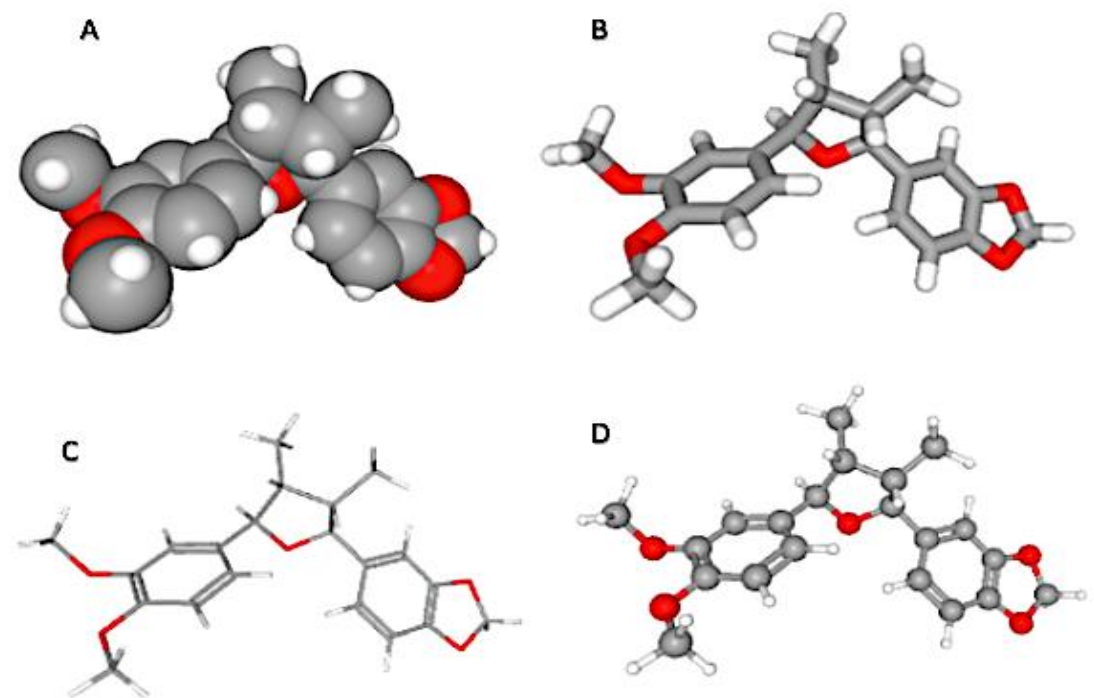

Figure 1: Structural representations of the Machilin G (A) Space-Filling (B) Sticks (C) Wireframe (D) Ball and Stick

\subsection{Geometric Optimization and Structural Properties}

As atoms do not present uniformity in real cases due to the electronic cloud, Geometry understands the organization between the arrangements of atoms, an important parameter to predict the polarity of a molecule. When a molecule is taken directly from a virtual repository, its conformation is not more stable[12][22][23][33][34]. In this case, the use of molecular modeling is introduced, an important tool to help the understanding of fundamental concepts of structure-activity relationships and mechanism of action of molecules One of the processes used in modeling is the process of geometric optimization, which, using theoretical calculations, seeks to retain each atom in its regions with lower levels of potential energy making the molecule thermodynamically more stable (explain what molecular geometry is)[35][36][37] [34]. The geometrically optimized Machilin G ligand (Figure 2) through semi-empirical quantum calculations, obtaining the structure theoretically close to its native form and energy, it is possible to structurally characterize atomic properties, connections and angles. When analyzing atomic properties, one can notice the presence of variations in the partial charges of atoms of the same nature since the carbon atoms ranged from -0.059 to 0.233 , the oxygen atoms from -0.491 to -0.364 and the hydrogens varying from 0.023 to 0.117. In the final geometry of Machilin $G$ after optimization, all the analyzed bonds were characterized by the predominance of covalence, where it can be highlight the bonds $(1,6,10,39$, 43, and 47) between carbon as second order bonds (Table S1- supplementary material). In addition, the links $(21,22,24,27$ and 30) between the carbons are known for their rotation (Table S2supplementary material). Complementing the conformational analysis, the largest and smallest angles between the joints were identified, angles 81 (CCO) and 39 (CCC) with $128.3547^{\circ}$ and $102.2908^{\circ}$ respectively; and at greater and lesser torsion angles, systems $123(\mathrm{CCCH})$ and 70 $(\mathrm{HCCH})$ with $179.9692^{\circ}$ and $-179.9499^{\circ}$ respectively (Table S3 and S4- supplementary material). 


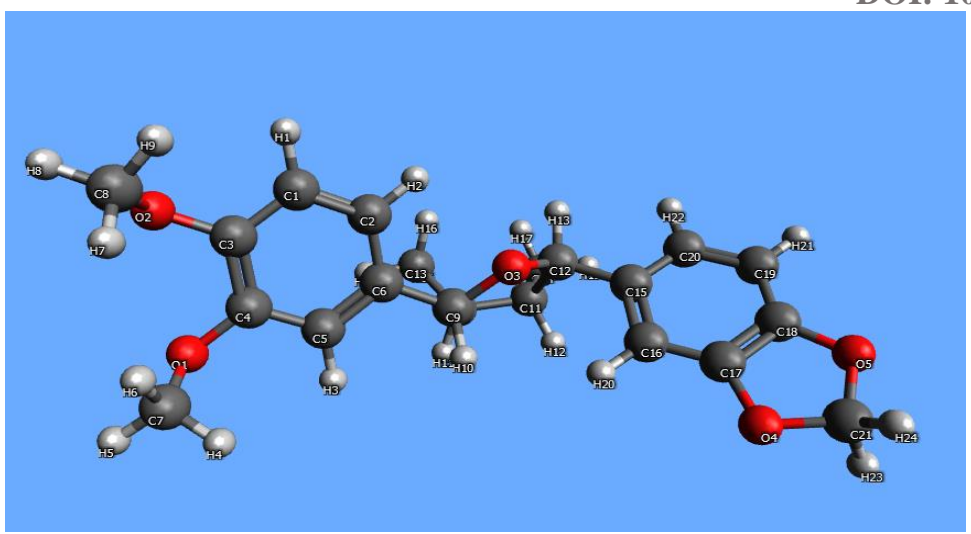

Figure 2: Optimized three-dimensional structure of the Machilin G

\subsection{Frontier Orbitals}

A category of chemical-quantum descriptors widely used in studies is related to the energy of the HOMO and LUMO frontier orbitals[37]. The HOMO is an orbital occupied with greater energy, it is linked to the ionization potential, and the electron-donating capacity of the molecule, the LUMO and showing the region where it has the highest electron density, LUMO is the unoccupied orbital with the lowest energy, is related to electronic affinity and with the ionization potential and electron-acceptor capacity of the compound, showing the lowest electronic density of the molecule. From these definitions, two important characteristics can be observed: the greater the energy of HOMO, the greater the electron-donor capacity and, the lower the energy of LUMO, the lower the resistance to accept electrons. The variation between the orbital limit values, called GAP, indicates the energy required for an electron to transition[34][38][39]. The greater the value of the difference, the lower the molecular reactivity and the greater the molecular capacity. Machilin G presented the energy value $-0.331477 \mathrm{eV}$ for the HOMO orbital and having atoms $\mathrm{C} 18, \mathrm{C} 20, \mathrm{C} 21$, C23, O24, O26, H40 AND H50 as contributors, where all showed symmetry between the positive and negative phases (Figure $3 \mathrm{~A}$ ). The LUMO orbital had an energy value of $0.000739 \mathrm{eV}$ with atoms C1, C2, C3, C4, C5, C6, C18, C19, C20, C21, C22, C23 showing symmetry between the positive and negative phases (Figure $3 \mathrm{~B}$ ).

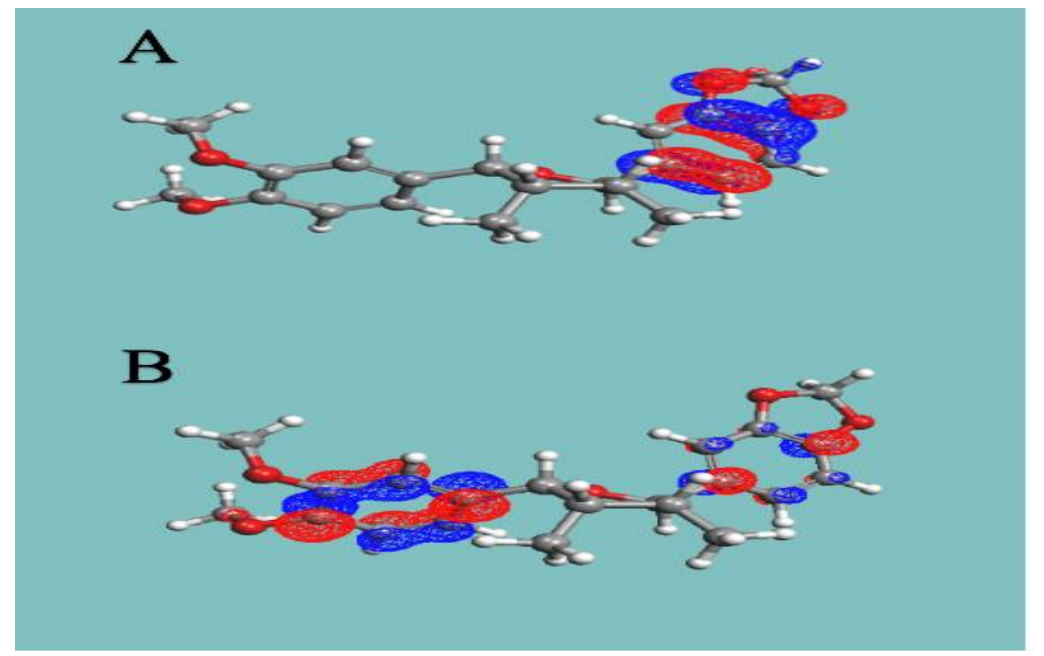

Figure 3: Frontier orbitals of the Machilin G HOMO (A) and LUMO (B) 


\subsection{Mulliken Population Analysis}

Mulliken atomic charges (Mulliken population analysis) and surface map of electrostatic potential Mulliken population analysis divides the charge densities between the atoms, regardless of electronegativity[40]. the same nature are notorious, where carbon atoms range from -0.3216 to 0.0620 , in oxygen -0.2564 to -0.1941 and hydrogen atoms from 0.0879 to 0.2173 [41][42]. The visualization and analysis of charges is possible through the surface map of potential electrostatics, as it allows to characterize electrophilic and nucleophilic regions, showing how complex molecules interact[43][44][45]. Through the MESP of Machilin G it was possible to perceive defined regions, since the regions in red signify regions with a high concentration of collections and the regions in white have a low concentration of charge. The regions highlighted in red are due to the presence of an oxygen atom, since they are more electronegative atoms than carbons and hydrogens (Figure 4)

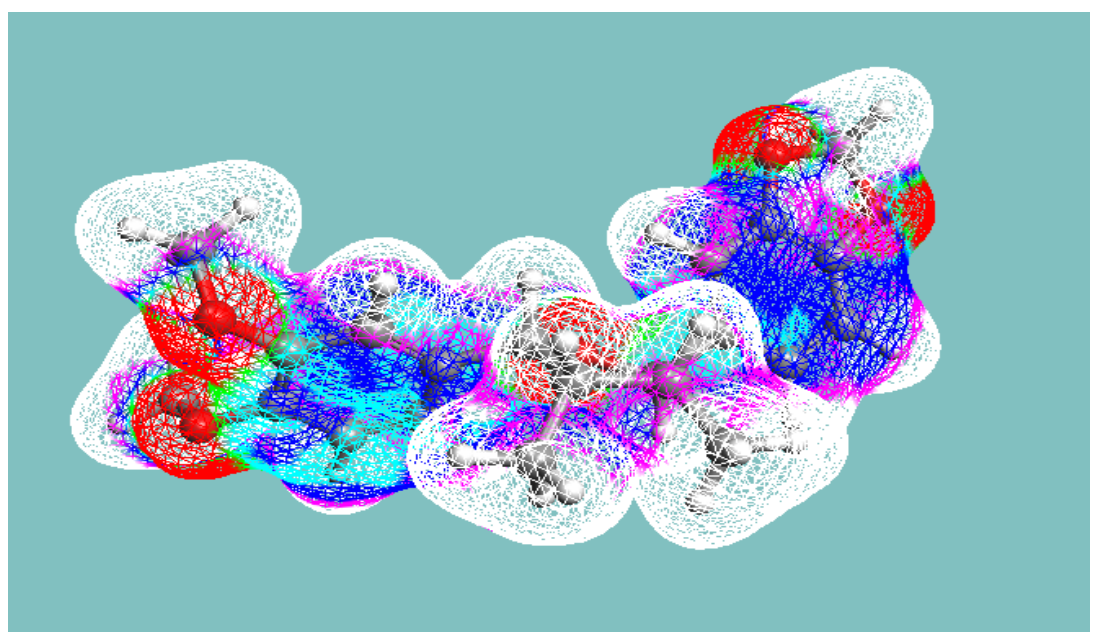

Figure 4: Machilin G electrostatic potential surface map (MESP)

\subsection{Molecular Docking}

The computational technique of molecular docking is one of the methods used in the therapeutic study of drugs where tests are carried out on possible bioactive molecules (ligands) for a given molecular target, the molecule can assume certain orientations of molecular fitting within the ligand site of the target, these processes involve energy such as the enthalpic (maximum energy of a system) and the entropic (thermodynamic energy related to chemical reactions)[17][34][46], through this it can be said that the molecular structure that presents less amount of energy necessary to bind to the active site, it will be the one that, theoretically, will perform the best result of biological activity. Through these coupling techniques, it was possible to discover new drugs that are increasingly improved, causing less damage to health[47][48].

The docking routines were performed with Machilin G and benznidazole (control), in which the simulations were classified based on the free binding energy [49] and the conformations that presented RMSD up to $2.0 \AA$ [50]Variations in the RMSD values from 0.907 to $1.653 \AA$ and affinity energies were observed from -7.8 to $-5.1 \mathrm{kcal} / \mathrm{mol}$ (Table 1) staying within the standards considered with valid positions for molecular docking. 
Table 1: RMSD and affinity energy values calculated in molecular docking simulations

\begin{tabular}{|l|l|c|c|}
\hline Enzyme & Ligand & RMSD $(\mathbf{A})$ & Affinity (kcal/mol) \\
\hline Cruzain & Benznidazole & 1.653 & -5.1 \\
\hline Cruzain & Machilin G & 1.206 & -6.9 \\
\hline TcGAPDH & Benznidazole & 1.876 & -5.5 \\
\hline TcGAPDH & Machilin G & 0.907 & -7.8 \\
\hline Tripanotiona Redutase & Benznidazole & 1.514 & -5.3 \\
\hline Tripanotiona Redutase & Machilin G & 1.507 & -7.6 \\
\hline
\end{tabular}

\subsection{Analysis of Molecular Docking Simulations Between Cruzain And Machilin G}

The enzyme Cruzain, a fundamental cysteine protease of $T$. cruzi, is a validated therapeutic molecular target for Chagas disease[25]. It is present during all stages of the parasite's evolutionary cycle and is essential for its nutrition and development. Belonging to the papain family in which it catalyzes hydrolysis reactions of peptide bonds. More specifically, it is responsible for the degradation of host cell proteins and, therefore, contributing to the infection process. Its crystallographic structure is composed of a polypeptide arrangement of 215 amino acids, folded into two domains, where one is predominantly $\alpha$-helix (C-terminal) and the other consists of extensive interactions of antiparallel ( $\mathrm{N}$-terminal) $\beta$-leaves. For enzymes of the papain family, there is an extensive gap between the two domains, where the catalytic site composed of the residues Cys25, His159 and Asn175, which form the so-called catalytic triad, is located[25]. The catalytic site has four binding subsites, determined as S1, S2, S3 and S1 '. The main one, the S2 subsite, is responsible for the specificity of the enzyme. Little exposed to the solvent, it is bounded by the side chains of hydrophobic residues, Met68, Ala133, Leu67, Leu157 and Gly160, being prone to groups of substances insoluble in water[25]. However, the presence and flexibility of the Glu205 residue at the end of this subsite gives it a negative characteristic, as it also allows interactions with positively charged groups. The S1, S3, and S1 'subsites are less defined and more exposed to the solvent, however they contain amino acid residues that are fundamental for catalytic activity. One of the residues of the catalytic triad, Cys 25 is present in the S1 subsite, as well as residues Gln19, Gly23, Ser64 and Leu67 [25][51]. In the S3 sub-site there are the residues Ser61, Gly65, Gly66 and Leu67, while in the S1 'sub-site are the other two residues of the catalytic triad Hys159 and Asn175, together with Asp161 and Trp184. With the Chimera[32] program it is possible to see the types of interactions of the amino acids that are present in the protein and ligand. The first to be done was that of Cruzain with the ligand Machilin G, the amino acids to be calculated distances were (Gln-19; Cys -25; Ser-61; Gly-65; Gly-66; Leu-67; Asp161; His162; Asn-182; Trp-184; Glu-208), comparing the distances of the benzonidazole ligands, KB2, Machilin G go that had the shortest distances between the ligand and the amino acid was KB2(Table 2). The ligand Machilin G presented the following interactions two interactions with Arg A: 10 (conventional hydrogen bond), a Phe A: 39 (pi-pi t-shaped) interaction, a Phe A: 39 (pialkyl) bond, a bond pro A: 44 (alkyl). Six van der walls interactions (His A: 43; Gly A: 42; Leu A: 40; Trp A: 7; Leu A: 45) (figure 5). 
Table 2: Distances between the Cruzain residues and the ligands

\begin{tabular}{|c|c|c|c|}
\hline Cruzain residue & Benznidazole & KB2 & Machiling \\
\hline Gln19 & $26.4 \AA$ & $3.1 \AA$ & 21.2 \\
\hline Cys25 & $23.8 \AA$ & $1.8 \AA$ & 21.8 \\
\hline Ser61 & $33.3 \AA$ & $2.8 \AA$ & 30.4 \\
\hline Gly65 & $30.4 \AA$ & $3.2 \AA$ & 29.4 \\
\hline Gly66 & $28.3 \AA$ & $2.9 \AA$ & 28.8 \\
\hline Leu67 & $25.0 \AA$ & $3.9 \AA$ & 26.2 \\
\hline Asp161 & $30.2 \AA$ & $3.4 \AA$ & 29.4 \\
\hline His162 & $26.0 \AA$ & $3.3 \AA$ & 24.0 \\
\hline Asn182 & $20.3 \AA$ & $7.7 \AA$ & 17.5 \\
\hline Trp184 & $26.9 \AA$ & $6.3 \AA$ & 22.2 \\
\hline Glu208 & $22.6 \AA$ & $4.0 \AA$ & 24.2 \\
\hline
\end{tabular}

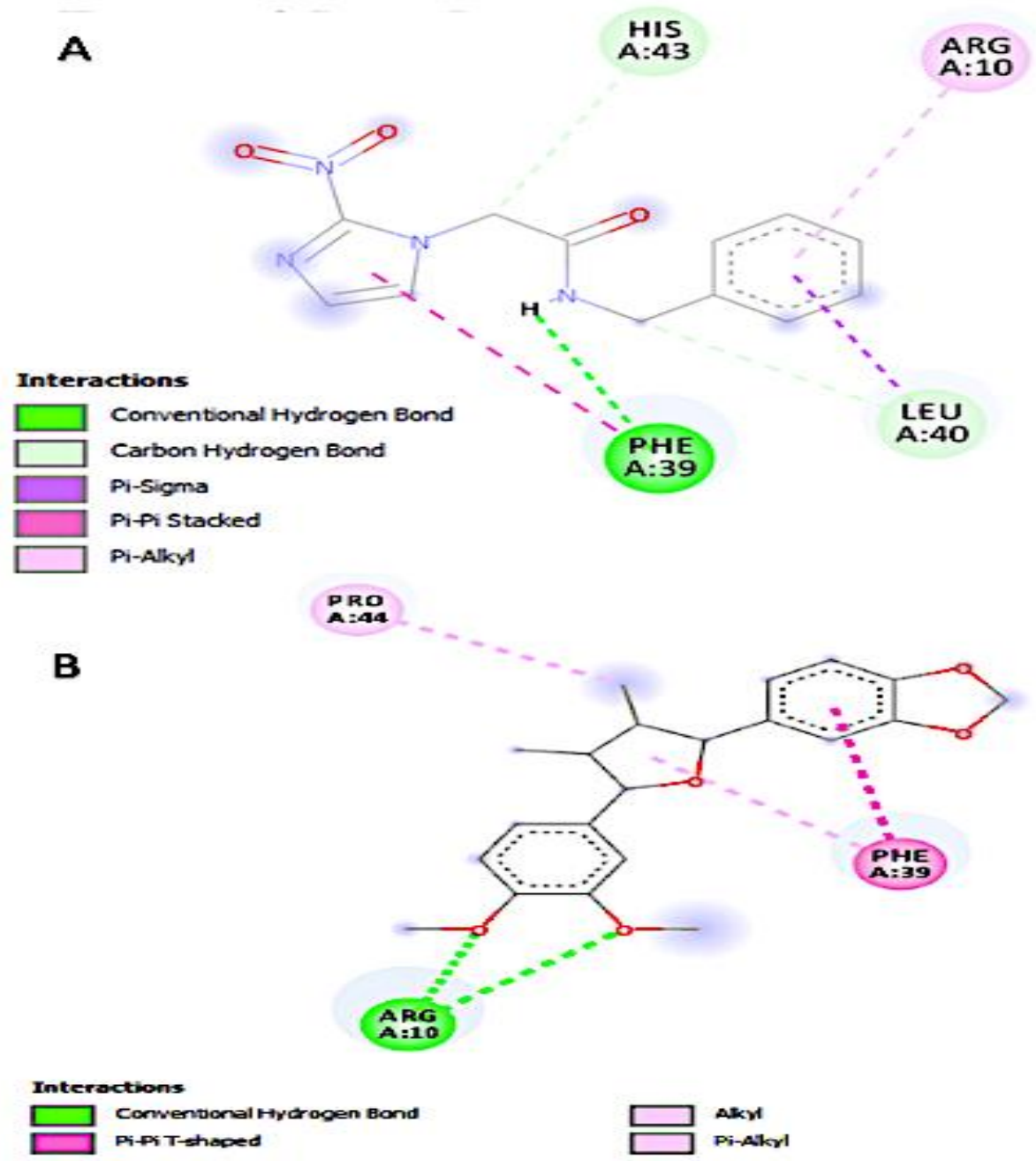

Figure 5: Two-dimensional molecular map for intermolecular interactions between Cruzain and Benznidazole (A), Machilin G (B). 


\subsection{Analysis of Molecular Docking Simulations Between Trypanosoma Cruzi Glyceraldehyde-3-Phosphate Dehydrogenase (Tcgapdh) And Machilin G}

The enzyme Trypanosoma cruzi glyceraldehyde-3-phosphate dehydrogenase (TcGAPDH)is characterized by being a tetramer enzyme with subunits of approximately 359 residues, known for being the sixth enzyme to participate in the glycolytic pathway in both humans and trypanosomes, thus catalyzing the conversion of glyceraldehyde-3-phosphate in 1,3-bisphosphoglycerate in the presence of the cofactor NAD + (essential for the biological activity of the enzyme), and inorganic phosphate. In $T$. cruzi the predominant intracellular trypanosomatides depend mainly on glycolysis for the production of ATP, inhibiting TcGAPDH would prevent $T$. cruzi from being infectious, this is one of the reasons why this enzyme is exploited as a therapeutic target by research[5] [26] [52][26] . Performing the distances with the TcGAPDH, the ligand Machilin G has rmsd 0.907, with an affinity of -7.8 , The amino acids that were performed the distances were (Ile13; Pro136; Cys166; Thr167; His194; Thr197; Asp210; Arg249)(Table 3), the types of interactions were 11 van der walls interactions (Pro c: 136, Ser c: 134, Arg c: 12, Ser c: 165, Thr c: 167, Val b: 203, Tyr c: 196, Glu c: 336, Thr c: 197, Ala c: 228, Thr c: 226) four conventional Hydrogen bond (Cys c: 166); (Asn c: 335); (Ala c: 198), a pi-donor pi-sulfur bond (pi- donor hydrogen bond) (Cys C: 166), a pi-sigma bond (His C: 194), a stacked pi-pi bond (His C: 194), a carbon hydrogen bond bond (Thr C: 226), two bonds alkyl (Ala C: 135); (ile: 13), a pi-alkyl bond (Ala C: 198). It can be seen that the ligand Machilin $\mathrm{G}$ interacted with a large part of the main amino acids Ile13 (van der alkyl bond), Pro136, Thr197, Thr197 (van der halls), Cys166 (conventional hydrogen bond), His194 (pi-sigma)(Figure 6).

Table 3: Distances between the TcGAPDH residues and the ligands

\begin{tabular}{|c|c|c|c|}
\hline TcGAPDH residue & Benznidazole Chalepin (BRZ) & Machilin G \\
\hline Ile13 & $3.6 \AA$ & $5.4 \AA$ & 3.7 \\
\hline Pro136 & $5.5 \AA$ & $6.3 \AA$ & 4.9 \\
\hline Cys166 & $3.8 \AA$ & $1.2 \AA$ & 3.7 \\
\hline Thr167 & $4.1 \AA$ & $3.7 \AA$ & 3.2 \\
\hline His194 & $3.3 \AA$ & $3.2 \AA$ & 3.1 \\
\hline Thr197 & $5.0 \AA$ & $4.4 \AA$ & 3.4 \\
\hline Asp210 & $7.5 \AA$ & $3.7 \AA$ & 8.5 \\
\hline Arg249 & $5.0 \AA$ & $3.3 \AA$ & 5.7 \\
\hline
\end{tabular}


A
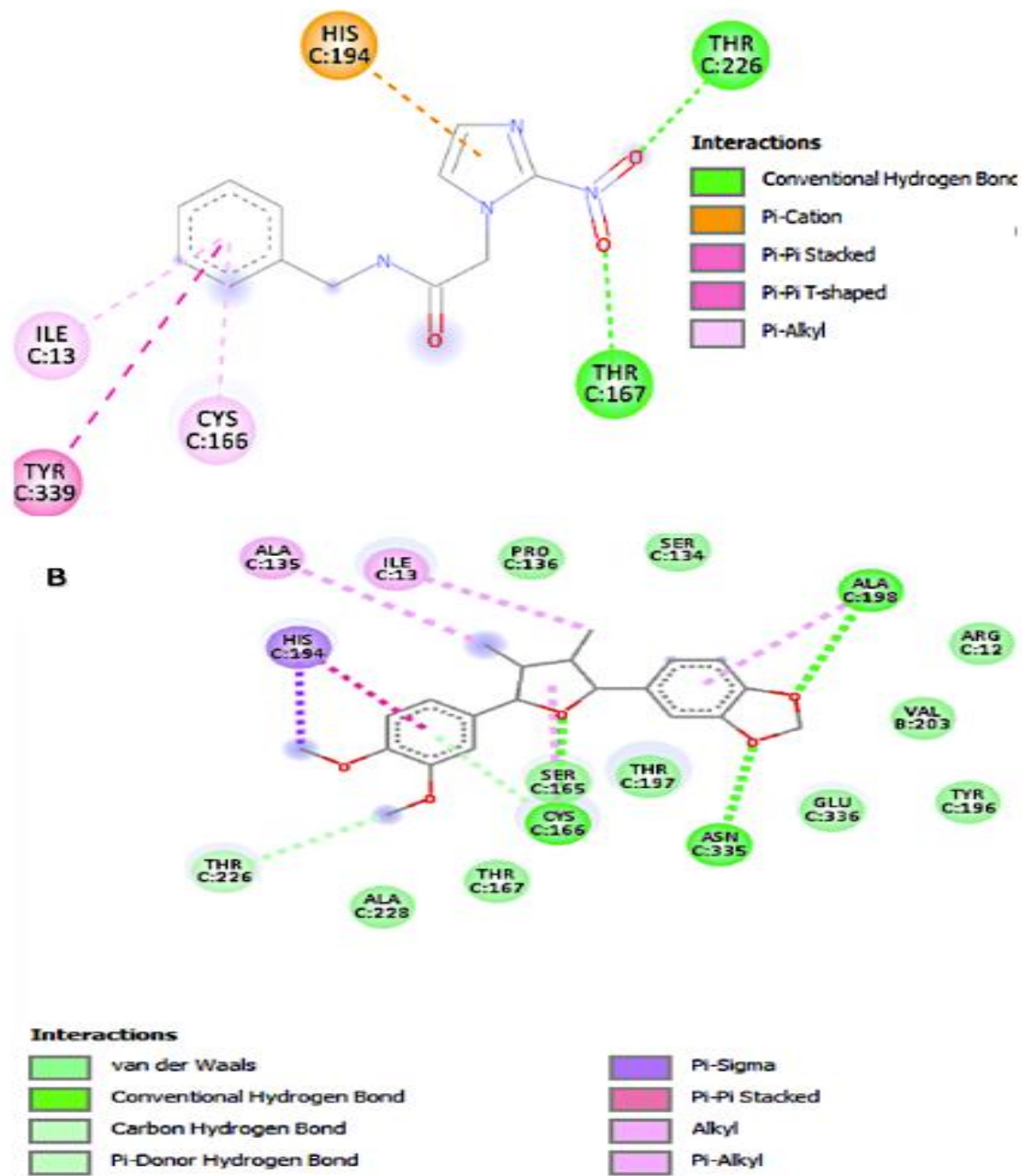

Figure 6: Two-dimensional molecular map for intermolecular interactions between glyceraldehyde-3-phosphate dehydrogenase (TcGAPDH) and Benznidazole (A), Machilin G (B)

\subsection{Analysis of Molecular Docking Simulations Between Trypanosoma Cruzi Tripanotiona Reductase (Tctr) And Machilin G}

The parasite, T. cruzi, has an essential enzyme called Tripanothione reductase (TcTR) a dimeric flavoprotein that belongs to the class of oxidoreductase enzymes, and is linked to the protection against oxidative stress of parasitic cells. performs the same cell protection function as human Glutathione Reductase (GR), T. cruzi Trypanothione Reductase (TcTR) allows the parasite to be unaffected by the defense mechanisms of the human host's immune system[27]. Biological and molecular genetic studies have shown that, in the absence of the Tripanothione reductasetrypanothione system, the parasite is more susceptible to oxidative stress, thus, it does not develop. One of the inhibitors used to work with this enzyme is quinacrine mustard, an alkylating derivative of the competitive inhibitor quinacrine that irreversibly inactivates Tripanothione reductase, but not human glutathione reductase. T. cruzi survival depends mainly on this enzyme. Therefore, the 
search for molecules that are selective to TcTR constitutes a promising field for the planning of drugs against Chagas disease [53][54][55]. It presented an rmsd of 1507, and an affinity of -7.6 four alkyl bonds ( Pro A: 336), two pi-sigma bonds (Ile A: 339), eight van der Waals interactions (Cys A: 53; Tyr A: 111; Thr A: 335; Asn A: 340; Glu A: 19; Arg A: 335; Ala A: 343; Asn A: 23). Interactions with the main residues of the type Glu19, Tyr111 (van der walls, and Ile339 (pisigma)) (Table 4) (Figure 7).

Table 4: Distances between the Trypanosoma cruzi Tripanotiona Reductase (TcTR) residues and the ligands

\begin{tabular}{|c|c|c|c|}
\hline Tripanotiona Reductase residue & Benznidazole Quinacrine Mustard (QUM) & Machilin G \\
\hline Ser15 & $13.4 \AA$ & $4.2 \AA$ & 4.9 \\
\hline Leu18 & $19.6 \AA$ & $3.2 \AA$ & 5.1 \\
\hline Glu19 & $18.1 \AA$ & $2.7 \AA$ & 3.5 \\
\hline Trp22 & $24.1 \AA$ & $3.5 \AA$ & 7.1 \\
\hline Ser110 & $26.4 \AA$ & $4.2 \AA$ & 9.9 \\
\hline Tyr111 & $19.5 \AA$ & $2.6 \AA$ & 4.0 \\
\hline Glu113 & $29.6 \AA$ & $1.5 \AA$ & 12.5 \\
\hline Met114 & $26.1 \AA$ & $3.3 \AA$ & 7.5 \\
\hline Asp117 & $33.0 \AA$ & $1.5 \AA$ & 14.7 \\
\hline Ile339 & $12.6 \AA$ & $3.5 \AA$ & 3.6 \\
\hline
\end{tabular}
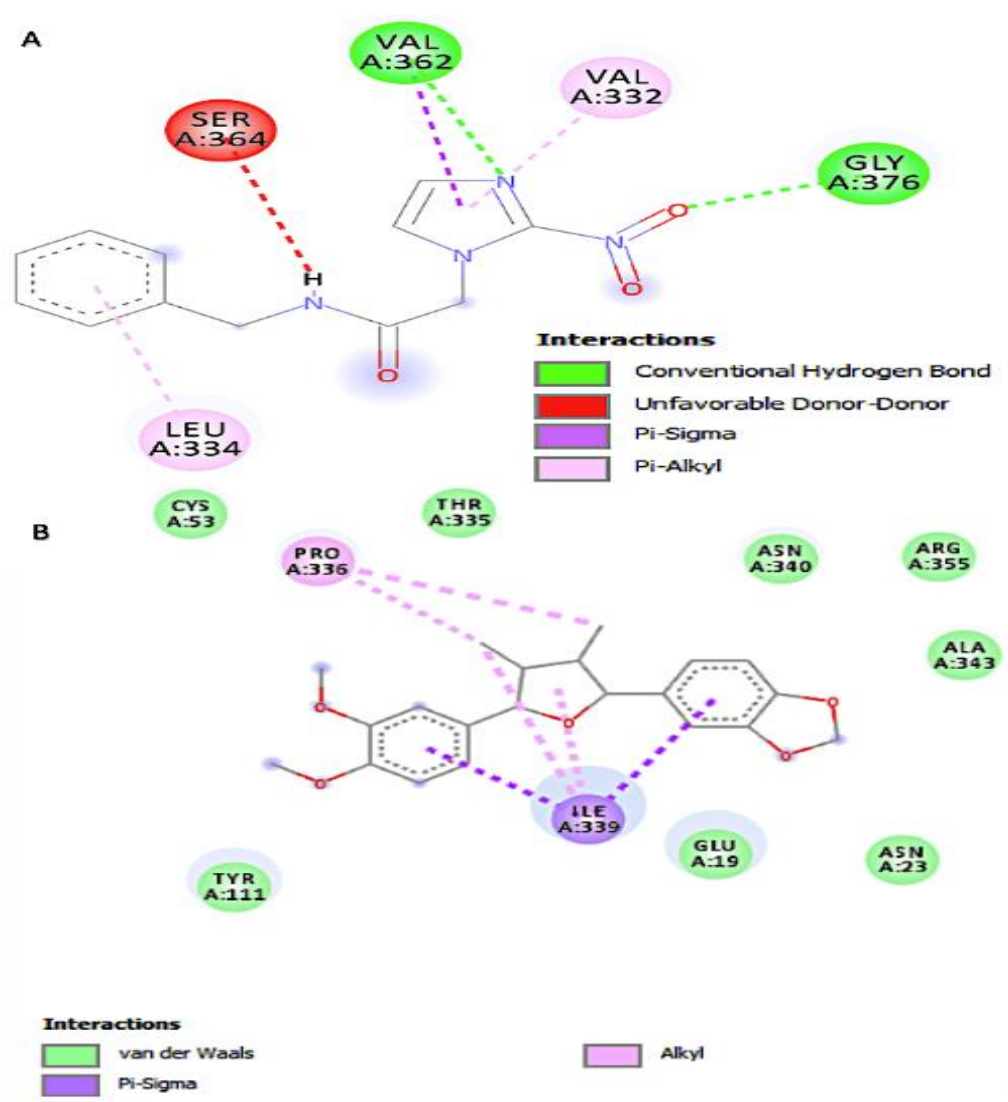

Fig. 7: Two-dimensional molecular map for intermolecular interactions between Tripanothione Reductase (TcTR) and Benznidazole (A), Machilin G (B) 


\section{Conclusions}

Machilin $\mathrm{G}$ was geometrically optimized using semi-empirical quantum calculations, through this technique it was possible to generate the thermodynamically more stable conformation. Through the method of analysis of the computational simulations of molecular anchoring it showed that the ligand Machilin $\mathrm{G}$ coupled in the active site of the enzyme TcGAPDH, in distances close to chalepin. Regarding Cruzain, it is possible to highlight that the ligand Machilin G did not interact with the amino acids of the active site of the enzyme, being at a considerable distance compared to the ligand KB2. With respect to the enzyme trypanothione reductase, the ligand Machilin $\mathrm{G}$ had few interactions with the amino acids of the active site. The intermolecular interactions found for the complex formed and the values obtained from the distance of the enzyme residues, indicate that Machilin $\mathrm{G}$ has potential application as a new inhibitor of the Trypanosoma cruzi TcGAPDH enzyme.

\section{Supplementary Material}

Table S1: Atomic properties of Machilin G after optimization, disregarding hydrogen atoms

\begin{tabular}{|l|c|c|c|c|c|c|c|}
\hline Atom & Element & Type & Valence & Partial Charge & $\mathbf{X}(\AA)$ & $\mathbf{Y}(\mathbf{A})$ & $\mathbf{Z}(\mathbf{\AA})$ \\
\hline 1 & C & Car & 3 & -0.016 & -1.80290 & -0.02160 & -1.34470 \\
\hline 2 & C & Car & 3 & -0.052 & -0.89900 & -1.05320 & -1.11990 \\
\hline 3 & C & Car & 3 & 0.162 & -1.87540 & 1.05070 & -0.44860 \\
\hline 4 & C & Car & 3 & 0.162 & -1.03230 & 1.07610 & 0.67820 \\
\hline 5 & C & Car & 3 & -0.011 & -0.11900 & 0.03840 & 0.89080 \\
\hline 6 & C & Car & 3 & -0.015 & -0.05250 & -1.02700 & -0.00950 \\
\hline 7 & O & O3 & 2 & -0.491 & -1.17150 & 2.07440 & 1.64280 \\
\hline 8 & C & C3 & 4 & 0,079 & -0.19790 & 3.09310 & 1.52580 \\
\hline 9 & O & O3 & 2 & -0.491 & -2.85020 & 2.03370 & -0.61560 \\
\hline 10 & C & C3 & 4 & 0.079 & -2.52380 & 2.96870 & -1.62530 \\
\hline 11 & C & C3 & 4 & 0.087 & 0.95080 & -2.12010 & 0.26520 \\
\hline 12 & C & C3 & 4 & -0.008 & 0.45960 & -3.20890 & 1.26280 \\
\hline 13 & C & C3 & 4 & -0.008 & 1.22800 & -4.46090 & 0.78370 \\
\hline 14 & C & C3 & 4 & 0.087 & 1,49380 & $-4,18110$ & $-0,71980$ \\
\hline 15 & O & O3 & 2 & -0.364 & 1.32600 & -2.77690 & -0.95600 \\
\hline 16 & C & C3 & 4 & -0.059 & -1.05000 & $-3,37080$ & 1.27680 \\
\hline 17 & C & C3 & 4 & -0.059 & 0.53140 & -5.78940 & 0.99730 \\
\hline 18 & C & Car & 3 & -0.015 & 2.87900 & -4.63060 & -1.12520 \\
\hline 19 & C & Car & 3 & -0.011 & 4.00050 & -3.83900 & -0.81630 \\
\hline 20 & C & Car & 3 & 0.167 & 5.22530 & -4.33820 & -1.21200 \\
\hline 21 & C & Car & 3 & 0.166 & 5.35360 & -5.57180 & -1.88020 \\
\hline 22 & C & Car & 3 & -0.016 & 4.25790 & -6.35650 & -2.18200 \\
\hline 23 & C & Car & 3 & -0.052 & 3.01070 & -5.85240 & -1.78750 \\
\hline 24 & O & O3 & 2 & -0.453 & 6.48280 & -3.76750 & -1.03840 \\
\hline 25 & C & C3 & 4 & 0.233 & 7.42100 & -4.68780 & -1.63250 \\
\hline 26 & O & O3 & 2 & -0.453 & 6.69460 & -5.82100 & -2.15170 \\
\hline 27 & H & H & 1 & 0.066 & -2.46220 & -0.04910 & -2.22020 \\
\hline
\end{tabular}


DOI: 10.5281/zenodo.3698202

\begin{tabular}{|l|l|l|l|l|l|l|l|}
\hline 28 & H & H & 1 & 0.062 & -0.85460 & -1.89420 & -1.82270 \\
\hline 29 & H & H & 1 & 0.066 & 0.54100 & 0.06390 & 1.76730 \\
\hline 30 & H & H & 1 & 0.066 & 0.81780 & 2.70110 & 1.65320 \\
\hline 31 & H & H & 1 & 0.066 & -0.45050 & 3.76830 & 2.34650 \\
\hline 32 & H & H & 1 & 0.066 & -0.27190 & 3.61840 & 0.56590 \\
\hline 33 & H & H & 1 & 0.066 & -1.63060 & 3.54890 & $-1,36390$ \\
\hline 34 & H & H & 1 & 0.066 & -3.40180 & 3.61830 & -1.65040 \\
\hline 35 & H & H & 1 & 0.066 & -2.37720 & 2.48780 & -2.59950 \\
\hline 36 & H & H & 1 & 0.065 & 1.89280 & -1.65420 & 0.64600 \\
\hline 37 & H & H & 1 & 0.033 & 0.78310 & -2.93640 & 2.29360 \\
\hline 38 & H & H & 1 & 0.033 & 2.0660 & -4.49360 & 1.32260 \\
\hline 39 & H & H & 1 & 0.065 & 0.72470 & -4.66330 & -1.36830 \\
\hline 40 & H & H & 1 & 0.023 & -1.53950 & $-2,43380$ & 1.57680 \\
\hline 41 & H & H & 1 & 0.023 & -1.36100 & -4.14910 & 1,98620 \\
\hline 42 & H & H & 1 & 0.023 & -1.44090 & -3.64230 & 0.28640 \\
\hline 43 & H & H & 1 & 0.023 & -0.43000 & -5.84630 & 0.46780 \\
\hline 44 & H & H & 1 & 0.023 & 0.33370 & $-5,96780$ & 2.06210 \\
\hline 45 & H & H & 1 & 0.023 & 1.15600 & -6.61440 & 0,62850 \\
\hline 46 & H & H & 1 & 0.066 & 3.89710 & -2.87800 & -0.30080 \\
\hline 47 & H & H & 1 & 0.066 & 4.35020 & -7.31430 & -2.70140 \\
\hline 48 & H & H & 1 & 0.062 & 2.11280 & -6.44280 & -2.00760 \\
\hline 49 & H & H & 1 & 0.117 & 8.12390 & -5.03430 & -0.85890 \\
\hline 50 & H & H & 1 & 0.117 & 7.94430 & -4.18480 & -2.46080 \\
\hline
\end{tabular}

Table S2: Properties of Machilin G bonds after optimization, disregarding hydrogen atoms

\begin{tabular}{|l|c|c|c|c|c|c|}
\hline Bond & Type & Start Storm & End Storm & Bond Order & Rotable & Lenght $(\mathbf{A})$ \\
\hline 1 & C-C & C1 & C2 & 2 & No & 1.38988 \\
\hline 2 & C-C & C1 & C3 & 1 & No & 1.39931 \\
\hline 3 & C-H & C1 & H1 & 1 & No & 1.09633 \\
\hline 4 & C-C & C2 & C6 & 1 & No & 1.39651 \\
\hline 5 & C-H & C2 & H2 & 1 & No & 1.0969 \\
\hline 6 & C-C & C3 & C4 & 2 & No & 1.40753 \\
\hline 7 & C-O & C3 & O2 & 1 & No & 1.39442 \\
\hline 8 & C-C & C4 & C5 & 1 & No & 1.39862 \\
\hline 9 & C-O & C4 & O1 & 1 & No & 1.39515 \\
\hline 10 & C-C & C5 & C6 & 2 & No & 1.39644 \\
\hline 11 & C-H & C5 & H3 & 1 & No & 1.0975 \\
\hline 12 & C-C & C6 & C9 & 1 & No & 1.50895 \\
\hline 13 & O-C & O1 & C7 & 1 & No & 1.41398 \\
\hline 14 & C-H & C7 & H4 & 1 & No & 1.09615 \\
\hline 15 & C-H & C7 & H5 & 1 & No & 1.09236 \\
\hline 16 & C-H & C7 & H6 & 1 & No & 1.09673 \\
\hline 17 & O-C & O2 & C8 & 1 & No & 1.4143 \\
\hline 18 & C-H & C8 & H7 & 1 & No & 1.09671 \\
\hline
\end{tabular}



DOI: 10.5281/zenodo.3698202

\begin{tabular}{|l|c|c|c|c|c|c|}
\hline 19 & C-H & C8 & H8 & 1 & No & 1.09247 \\
\hline 20 & C-H & C8 & H9 & 1 & No & 1.09628 \\
\hline 21 & C-C & C9 & C10 & 1 & Yes & 1.55627 \\
\hline 22 & C-O & C9 & O3 & 1 & Yes & 1.43649 \\
\hline 23 & C-H & C9 & H10 & 1 & No & 1.11778 \\
\hline 24 & C-C & C10 & C11 & 1 & Yes & 1.54515 \\
\hline 25 & C-C & C10 & C13 & 1 & No & 1.51832 \\
\hline 26 & C-H & C10 & H11 & 1 & No & 1.11421 \\
\hline 27 & C-C & C11 & C12 & 1 & Yes & 1.55224 \\
\hline 28 & C-C & C11 & C14 & 1 & No & 1.51519 \\
\hline 29 & C-H & C11 & H12 & 1 & No & 1.11765 \\
\hline 30 & C-O & C12 & O3 & 1 & Yes & 1.43378 \\
\hline 31 & C-C & C12 & C15 & 1 & No & 1.51168 \\
\hline 32 & C-H & C12 & H13 & 1 & No & 1.11561 \\
\hline 33 & C-H & C13 & H14 & 1 & No & 1.0989 \\
\hline 34 & C-H & C13 & H15 & 1 & No & 1.09805 \\
\hline 35 & C-H & C13 & H16 & 1 & No & 1.09882 \\
\hline 36 & C-H & C14 & H17 & 1 & No & 1.09904 \\
\hline 37 & C-H & C14 & H18 & 1 & No & 1.09759 \\
\hline 38 & C-H & C14 & H19 & 1 & No & 1.09853 \\
\hline 39 & C-C & C15 & C16 & 2 & No & 1.40706 \\
\hline 40 & C-C & C15 & C20 & 1 & No & 1.39599 \\
\hline 41 & C-C & C16 & C17 & 1 & No & 1.38055 \\
\hline 42 & C-H & C16 & H20 & 1 & No & 1.09542 \\
\hline 43 & C-C & C17 & C18 & 2 & No & 1.4088 \\
\hline 44 & C-O & C17 & O4 & 1 & No & 1.39181 \\
\hline 45 & C-C & C18 & C19 & 1 & No & 1.38109 \\
\hline 46 & C-O & C18 & O5 & 1 & No & 1.39072 \\
\hline 47 & C-C & C19 & C20 & 2 & No & 1.40188 \\
\hline 48 & C-H & C19 & H21 & 1 & No & 1.09347 \\
\hline 49 & C-H & C20 & H22 & 1 & No & 1.09692 \\
\hline 50 & O-C & O4 & C21 & 1 & No & 1.44226 \\
\hline 51 & C-O & C21 & O5 & 1 & No & 1.44269 \\
\hline 52 & C-H & C21 & H23 & 1 & No & 1.10118 \\
\hline 53 & C-H & C21 & H24 & 1 & no & 1.10133 \\
\hline & & & & & & \\
\hline
\end{tabular}

Table S3: Angle properties of Machilin G after optimization, disregarding hydrogen atoms

\begin{tabular}{|l|c|c|c|c|c|}
\hline Angle & Type & Start Atom & Vertex & End Atom & Angle $\left(^{\circ}\right)$ \\
\hline 1 & CCC & C2 & C1 & C 3 & 119.9264 \\
\hline 2 & CCH & C2 & C1 & H1 & 120.1087 \\
\hline 3 & CCH & C 3 & C1 & H1 & 119.9643 \\
\hline 4 & CCC & C1 & C2 & C6 & 120.5898 \\
\hline
\end{tabular}



DOI: 10.5281/zenodo.3698202

\begin{tabular}{|c|c|c|c|c|c|}
\hline 5 & $\mathrm{CCH}$ & $\mathrm{C} 1$ & $\mathrm{C} 2$ & $\mathrm{H} 2$ & 119.4565 \\
\hline 6 & $\mathrm{CCH}$ & C6 & $\mathrm{C} 2$ & $\mathrm{H} 2$ & 119.9536 \\
\hline 7 & $\mathrm{CCC}$ & $\mathrm{C} 1$ & C3 & $\mathrm{C} 4$ & 119.6998 \\
\hline 8 & $\mathrm{CCO}$ & $\mathrm{C} 1$ & C3 & $\mathrm{O} 2$ & 119.9823 \\
\hline 9 & $\mathrm{CCO}$ & $\mathrm{C} 4$ & C3 & $\mathrm{O} 2$ & 120.1253 \\
\hline 10 & $\mathrm{CCC}$ & C3 & $\mathrm{C} 4$ & $\mathrm{C} 5$ & 119.9632 \\
\hline 11 & $\mathrm{CCO}$ & C3 & $\mathrm{C} 4$ & $\mathrm{O} 1$ & 120.4408 \\
\hline 12 & $\mathrm{CCO}$ & C5 & $\mathrm{C} 4$ & O1 & 119.4035 \\
\hline 13 & $\mathrm{CCC}$ & $\mathrm{C} 4$ & $\mathrm{C} 5$ & C6 & 119.9442 \\
\hline 14 & $\mathrm{CCH}$ & $\mathrm{C} 4$ & $\mathrm{C5}$ & $\mathrm{H} 3$ & 119.7920 \\
\hline 15 & $\mathrm{CCH}$ & C6 & $\mathrm{C} 5$ & H3 & 120.2635 \\
\hline 16 & $\mathrm{CCC}$ & $\mathrm{C} 2$ & C6 & C5 & 119.8727 \\
\hline 17 & $\mathrm{CCC}$ & $\mathrm{C} 2$ & C6 & C9 & 122.2890 \\
\hline 18 & $\mathrm{CCC}$ & $\mathrm{C} 5$ & C6 & C9 & 117.8383 \\
\hline 19 & $\mathrm{COC}$ & $\mathrm{C} 4$ & O1 & $\mathrm{C} 7$ & 112.9302 \\
\hline 20 & $\mathrm{OCH}$ & O1 & $\mathrm{C} 7$ & $\mathrm{H} 4$ & 111.7624 \\
\hline 21 & $\mathrm{OCH}$ & O1 & C7 & $\mathrm{H} 5$ & 102.9398 \\
\hline 22 & $\mathrm{OCH}$ & $\mathrm{O} 1$ & $\mathrm{C} 7$ & H6 & 111.7794 \\
\hline 23 & $\mathrm{HCH}$ & $\mathrm{H} 4$ & $\mathrm{C} 7$ & H5 & 110.3648 \\
\hline 24 & $\mathrm{HCH}$ & $\mathrm{H} 4$ & C7 & H6 & 109.6049 \\
\hline 25 & $\mathrm{HCH}$ & $\mathrm{H} 5$ & C7 & H6 & 110.2376 \\
\hline 26 & $\mathrm{COC}$ & $\mathrm{C} 3$ & $\mathrm{O} 2$ & $\mathrm{C} 8$ & 112.9677 \\
\hline 27 & $\mathrm{OCH}$ & $\mathrm{O} 2$ & $\mathrm{C} 8$ & $\mathrm{H} 7$ & 111.5643 \\
\hline 28 & $\mathrm{OCH}$ & $\mathrm{O} 2$ & $\mathrm{C} 8$ & H8 & 102.9456 \\
\hline 29 & $\mathrm{OCH}$ & $\mathrm{O} 2$ & $\mathrm{C} 8$ & H9 & 112.0416 \\
\hline 30 & $\mathrm{HCH}$ & $\mathrm{H} 7$ & $\mathrm{C} 8$ & $\mathrm{H} 8$ & 110.2093 \\
\hline 31 & $\mathrm{HCH}$ & $\mathrm{H7}$ & $\mathrm{C} 8$ & H9 & 109.5706 \\
\hline 32 & $\mathrm{HCH}$ & H8 & $\mathrm{C} 8$ & H9 & 110.3585 \\
\hline 33 & $\mathrm{CCC}$ & C6 & C9 & $\mathrm{C} 10$ & 114.4343 \\
\hline 34 & $\mathrm{CCO}$ & C6 & C9 & $\mathrm{O} 3$ & 110.4948 \\
\hline 35 & $\mathrm{CCH}$ & C6 & C9 & $\mathrm{H} 10$ & 108.6881 \\
\hline 36 & $\mathrm{CCO}$ & $\mathrm{C} 10$ & C9 & $\mathrm{O} 3$ & 107.9089 \\
\hline 37 & $\mathrm{CCH}$ & $\mathrm{C} 10$ & C9 & $\mathrm{H} 10$ & 109.8294 \\
\hline 38 & $\mathrm{OCH}$ & $\mathrm{O} 3$ & C9 & H10 & 105.0746 \\
\hline 39 & $\mathrm{CCC}$ & C9 & $\mathrm{C} 10$ & C11 & 102.1908 \\
\hline 40 & $\mathrm{CCC}$ & C9 & $\mathrm{C} 10$ & C13 & 113.2239 \\
\hline 41 & $\mathrm{CCH}$ & C9 & $\mathrm{C} 10$ & H11 & 109.2864 \\
\hline 42 & $\mathrm{CCC}$ & C11 & C10 & C13 & 114.2614 \\
\hline 43 & $\mathrm{CCH}$ & C11 & C10 & H11 & 109.9158 \\
\hline 44 & $\mathrm{CCH}$ & C13 & C10 & H11 & 107.8317 \\
\hline 45 & $\mathrm{CCC}$ & $\mathrm{C} 10$ & C11 & $\mathrm{C} 12$ & 103.8529 \\
\hline 46 & $\mathrm{CCC}$ & $\mathrm{C} 10$ & C11 & $\mathrm{C} 14$ & 115.9829 \\
\hline 47 & $\mathrm{CCH}$ & $\mathrm{C} 10$ & C11 & H12 & 108.0369 \\
\hline 48 & $\mathrm{CCC}$ & $\mathrm{C} 12$ & C11 & C14 & 111.9204 \\
\hline
\end{tabular}



DOI: 10.5281/zenodo.3698202

\begin{tabular}{|c|c|c|c|c|c|}
\hline 49 & $\mathrm{CCH}$ & $\mathrm{C} 12$ & $\mathrm{C} 11$ & H12 & 108.8065 \\
\hline 50 & $\mathrm{CCH}$ & $\mathrm{C} 12$ & $\mathrm{C} 11$ & H12 & 107.9942 \\
\hline 51 & $\mathrm{CCO}$ & $\mathrm{C} 11$ & $\mathrm{C} 12$ & $\mathrm{O} 3$ & 108.4250 \\
\hline 52 & $\mathrm{CCC}$ & C11 & $\mathrm{C} 12$ & $\mathrm{C} 15$ & 111.2887 \\
\hline 53 & $\mathrm{CCH}$ & C11 & $\mathrm{C} 12$ & H13 & 111.5358 \\
\hline 54 & OCC & $\mathrm{O} 3$ & C12 & $\mathrm{C} 15$ & 110.7492 \\
\hline 55 & $\mathrm{OCH}$ & $\mathrm{O} 3$ & $\mathrm{C} 12$ & H13 & 104.2922 \\
\hline 56 & $\mathrm{CCH}$ & C15 & C12 & H13 & 110.3224 \\
\hline 57 & $\mathrm{COC}$ & C9 & $\mathrm{O} 3$ & C12 & 109.7741 \\
\hline 58 & $\mathrm{CCH}$ & $\mathrm{C} 10$ & C13 & H14 & 110.7618 \\
\hline 59 & $\mathrm{CCH}$ & $\mathrm{C} 10$ & $\mathrm{C} 13$ & H15 & 111.2931 \\
\hline 60 & $\mathrm{CCH}$ & $\mathrm{C} 10$ & $\mathrm{C} 13$ & H16 & 111.8228 \\
\hline 61 & $\mathrm{HCH}$ & H14 & C13 & H15 & 107.5680 \\
\hline 62 & $\mathrm{HCH}$ & H14 & $\mathrm{C} 13$ & H16 & 107.3543 \\
\hline 63 & $\mathrm{HCH}$ & H15 & $\mathrm{C} 13$ & H16 & 107.3543 \\
\hline 64 & $\mathrm{CCH}$ & C11 & $\mathrm{C} 14$ & H17 & 112.3115 \\
\hline 65 & $\mathrm{CCH}$ & C11 & $\mathrm{C} 14$ & H18 & 112.3115 \\
\hline 66 & $\mathrm{CCH}$ & $\mathrm{C} 11$ & $\mathrm{C} 14$ & H19 & 107.8206 \\
\hline 67 & $\mathrm{HCH}$ & $\mathrm{H} 17$ & $\mathrm{C} 14$ & H18 & 107.5423 \\
\hline 68 & $\mathrm{HCH}$ & H17 & $\mathrm{C} 14$ & H19 & 107.2622 \\
\hline 69 & $\mathrm{HCH}$ & H18 & C14 & H19 & 107.8206 \\
\hline 70 & $\mathrm{CCC}$ & C12 & C15 & C16 & 120.2784 \\
\hline 71 & $\mathrm{CCC}$ & $\mathrm{C} 12$ & $\mathrm{C} 15$ & $\mathrm{C} 20$ & 118.2896 \\
\hline 72 & $\mathrm{CCC}$ & $\mathrm{C} 16$ & $\mathrm{C} 15$ & $\mathrm{C} 20$ & 121.4230 \\
\hline 73 & $\mathrm{CCC}$ & $\mathrm{C} 15$ & $\mathrm{C} 16$ & $\mathrm{C} 17$ & 116.1535 \\
\hline 74 & $\mathrm{CCH}$ & $\mathrm{C} 15$ & $\mathrm{C} 16$ & $\mathrm{H} 20$ & 121.4417 \\
\hline 75 & $\mathrm{CCH}$ & $\mathrm{C} 17$ & $\mathrm{C} 16$ & $\mathrm{H} 20$ & 122.4016 \\
\hline 76 & $\mathrm{CCC}$ & $\mathrm{C} 16$ & $\mathrm{C} 17$ & C18 & 122.2335 \\
\hline 77 & $\mathrm{CCO}$ & C16 & C17 & $\mathrm{O} 4$ & 128.1374 \\
\hline 78 & $\mathrm{CCO}$ & C18 & $\mathrm{C} 17$ & $\mathrm{O} 4$ & 109.6288 \\
\hline 79 & $\mathrm{CCC}$ & $\mathrm{C} 17$ & $\mathrm{C} 18$ & C19 & 121.9320 \\
\hline 80 & $\mathrm{CCO}$ & $\mathrm{C} 17$ & $\mathrm{C} 18$ & $\mathrm{O5}$ & 109.7133 \\
\hline 81 & $\mathrm{CCO}$ & $\mathrm{C} 19$ & $\mathrm{C} 18$ & $\mathrm{O5}$ & 128.3547 \\
\hline 82 & $\mathrm{CCC}$ & C18 & $\mathrm{C} 19$ & $\mathrm{C} 20$ & 116.1053 \\
\hline 83 & $\mathrm{CCH}$ & $\mathrm{C} 18$ & C19 & $\mathrm{H} 21$ & 122.3109 \\
\hline 84 & $\mathrm{CCH}$ & C20 & C19 & $\mathrm{H} 21$ & 121.5835 \\
\hline 85 & $\mathrm{CCC}$ & $\mathrm{C} 15$ & $\mathrm{C} 20$ & C19 & 122.1517 \\
\hline 86 & $\mathrm{CCH}$ & $\mathrm{C} 15$ & $\mathrm{C} 20$ & $\mathrm{H} 22$ & 119.2778 \\
\hline 87 & $\mathrm{CCH}$ & $\mathrm{C} 19$ & $\mathrm{C} 20$ & $\mathrm{H} 22$ & 118.5704 \\
\hline 88 & $\mathrm{COC}$ & $\mathrm{C} 17$ & $\mathrm{O} 4$ & $\mathrm{C} 21$ & 105.9445 \\
\hline 89 & $\mathrm{OCO}$ & $\mathrm{O} 4$ & $\mathrm{C} 21$ & O5 & 108.7790 \\
\hline 90 & $\mathrm{OCH}$ & $\mathrm{O} 4$ & $\mathrm{C} 21$ & $\mathrm{H} 23$ & 109.0643 \\
\hline 91 & $\mathrm{OCH}$ & $\mathrm{O} 4$ & C21 & $\mathrm{H} 24$ & 109.1147 \\
\hline
\end{tabular}



DOI: 10.5281/zenodo.3698202

\begin{tabular}{|l|c|c|c|c|c|}
\hline 92 & OCH & O5 & C21 & H23 & 109.0904 \\
\hline 93 & OCH & O5 & C21 & H24 & 109.1061 \\
\hline 94 & HCH & H23 & C21 & H24 & 111.6400 \\
\hline 95 & COC & C18 & O5 & C21 & 105.9321 \\
\hline
\end{tabular}

Table S4: Torsional properties of Machilin $\mathrm{G}$ after optimization, disregarding hydrogen atoms

\begin{tabular}{|c|c|c|c|c|c|c|}
\hline Torsion & Type & Atom 1 & Atom 2 & Atom 3 & Atom 4 & Torsion $\left(^{\circ}\right)$ \\
\hline 1 & $\mathrm{CCCC}$ & C3 & $\mathrm{C} 1$ & $\mathrm{C} 2$ & C6 & -0.4244 \\
\hline 2 & $\mathrm{CCCH}$ & C3 & $\mathrm{C} 1$ & $\mathrm{C} 2$ & $\mathrm{H} 2$ & 179.4829 \\
\hline 3 & HCCC & $\mathrm{H} 1$ & $\mathrm{C} 1$ & $\mathrm{C} 2$ & C6 & 179.8629 \\
\hline 4 & $\mathrm{HCCH}$ & $\mathrm{H} 1$ & $\mathrm{C} 1$ & $\mathrm{C} 2$ & $\mathrm{H} 2$ & -0.2298 \\
\hline 5 & $\mathrm{CCCC}$ & $\mathrm{C} 2$ & C1 & C3 & $\mathrm{C} 4$ & -0.1191 \\
\hline 6 & $\mathrm{CCCO}$ & $\mathrm{C} 2$ & $\mathrm{C} 1$ & C3 & $\mathrm{O} 2$ & -175.0833 \\
\hline 7 & HCCC & H1 & C1 & C3 & $\mathrm{C} 4$ & 179.5940 \\
\hline 8 & $\mathrm{HCCO}$ & H1 & $\mathrm{C} 1$ & C3 & $\mathrm{O} 2$ & 4.6298 \\
\hline 9 & $\mathrm{CCCC}$ & C1 & $\mathrm{C} 2$ & C6 & $\mathrm{C} 5$ & 0.4950 \\
\hline 10 & $\mathrm{CCCC}$ & $\mathrm{C} 1$ & $\mathrm{C} 2$ & C6 & C9 & -179.4713 \\
\hline 11 & HCCC & $\mathrm{H} 2$ & $\mathrm{C} 2$ & C6 & $\mathrm{C} 5$ & -179.4118 \\
\hline 12 & HCCC & $\mathrm{H} 2$ & $\mathrm{C} 2$ & C6 & C9 & 0.6219 \\
\hline 13 & $\mathrm{CCCC}$ & $\mathrm{C} 1$ & C3 & $\mathrm{C} 4$ & $\mathrm{C} 5$ & 0.5907 \\
\hline 14 & $\mathrm{CCCO}$ & $\mathrm{C} 1$ & C3 & $\mathrm{C} 4$ & $\mathrm{O} 1$ & -174.3365 \\
\hline 15 & OCCC & $\mathrm{O} 2$ & C3 & $\mathrm{C} 4$ & $\mathrm{C} 5$ & 175.5476 \\
\hline 16 & OCCO & $\mathrm{O} 2$ & C3 & $\mathrm{C} 4$ & $\mathrm{O} 1$ & 0.6204 \\
\hline 17 & $\mathrm{CCOC}$ & $\mathrm{C} 1$ & C3 & $\mathrm{O} 2$ & $\mathrm{C} 8$ & -78.6072 \\
\hline 18 & $\mathrm{CCOC}$ & $\mathrm{C} 4$ & C3 & $\mathrm{O} 2$ & $\mathrm{C} 8$ & 106.4503 \\
\hline 19 & CCCC & C3 & $\mathrm{C} 4$ & $\mathrm{C} 5$ & C6 & -0.5215 \\
\hline 20 & $\mathrm{CCCH}$ & C3 & $\mathrm{C} 4$ & $\mathrm{C} 5$ & $\mathrm{H} 3$ & 179.6546 \\
\hline 21 & $\mathrm{OCCC}$ & $\mathrm{O} 1$ & $\mathrm{C} 4$ & $\mathrm{C} 5$ & C6 & 174.4584 \\
\hline 22 & $\mathrm{OCCH}$ & O1 & $\mathrm{C} 4$ & C5 & H3 & -5.3654 \\
\hline 23 & $\mathrm{CCOC}$ & C3 & $\mathrm{C} 4$ & O1 & C7 & -101.7578 \\
\hline 24 & $\mathrm{CCOC}$ & C5 & $\mathrm{C} 4$ & O1 & C7 & 83.2867 \\
\hline 25 & CCCC & $\mathrm{C} 4$ & $\mathrm{C} 5$ & C6 & $\mathrm{C} 2$ & -0.0184 \\
\hline 26 & CCCC & $\mathrm{C} 4$ & $\mathrm{C} 5$ & C6 & C9 & 179.9495 \\
\hline 27 & HCCC & H3 & $\mathrm{C} 5$ & C6 & $\mathrm{C} 2$ & 179.8046 \\
\hline 28 & HCCC & $\mathrm{H} 3$ & $\mathrm{C} 5$ & C6 & C9 & -0.2275 \\
\hline 29 & $\mathrm{CCCC}$ & $\mathrm{C} 2$ & C6 & C9 & $\mathrm{C} 10$ & -96.2868 \\
\hline 30 & $\mathrm{CCCO}$ & $\mathrm{C} 2$ & C6 & C9 & $\mathrm{O} 3$ & 25.7459 \\
\hline 31 & $\mathrm{CCCH}$ & $\mathrm{C} 2$ & C6 & C9 & $\mathrm{H} 10$ & 140.5512 \\
\hline 32 & CCCC & $\mathrm{C} 5$ & C6 & C9 & $\mathrm{C} 10$ & 83.7462 \\
\hline 33 & $\mathrm{CCCO}$ & C5 & C6 & C9 & $\mathrm{O} 3$ & -154.2211 \\
\hline 34 & $\mathrm{CCCH}$ & $\mathrm{C} 5$ & C6 & C9 & $\mathrm{H} 10$ & -39.4158 \\
\hline 35 & $\mathrm{COCH}$ & $\mathrm{C} 4$ & $\mathrm{O} 1$ & $\mathrm{C} 7$ & $\mathrm{H} 4$ & -61.1714 \\
\hline 36 & $\mathrm{COCH}$ & $\mathrm{C} 4$ & $\mathrm{O} 1$ & C7 & $\mathrm{H} 5$ & -179.6082 \\
\hline 37 & $\mathrm{COCH}$ & $\mathrm{C} 4$ & $\mathrm{O} 1$ & $\mathrm{C} 7$ & H6 & 62.0967 \\
\hline
\end{tabular}



DOI: 10.5281/zenodo.3698202

\begin{tabular}{|c|c|c|c|c|c|c|}
\hline 38 & $\mathrm{COCH}$ & C3 & $\mathrm{O} 2$ & $\mathrm{C} 8$ & $\mathrm{H7}$ & -64.5199 \\
\hline 39 & $\mathrm{COCH}$ & C3 & $\mathrm{O} 2$ & $\mathrm{C} 8$ & $\mathrm{H} 8$ & 177.3169 \\
\hline 40 & $\mathrm{COCH}$ & C3 & $\mathrm{O} 2$ & $\mathrm{C} 8$ & H9 & 58.7503 \\
\hline 41 & $\mathrm{CCCC}$ & C6 & C9 & $\mathrm{C} 10$ & $\mathrm{C} 11$ & 150.4081 \\
\hline 42 & $\mathrm{CCCC}$ & C6 & C9 & $\mathrm{C} 10$ & $\mathrm{C} 13$ & 27.0308 \\
\hline 43 & $\mathrm{CCCH}$ & C6 & C9 & $\mathrm{C} 10$ & H11 & -93.1803 \\
\hline 44 & OCCC & $\mathrm{O} 3$ & C9 & $\mathrm{C} 10$ & C11 & 26.9742 \\
\hline 45 & OCCC & $\mathrm{O} 3$ & C9 & $\mathrm{C} 10$ & $\mathrm{C} 13$ & -96.4031 \\
\hline 46 & $\mathrm{OCCH}$ & $\mathrm{O} 3$ & C9 & $\mathrm{C} 10$ & H11 & 143.3858 \\
\hline 47 & HCCC & H10 & C9 & $\mathrm{C} 10$ & C11 & -87.0473 \\
\hline 48 & HCCC & $\mathrm{H} 10$ & C9 & $\mathrm{C} 10$ & C13 & 149.5754 \\
\hline 49 & $\mathrm{HCCH}$ & $\mathrm{H} 10$ & C9 & $\mathrm{C} 10$ & H11 & 29.3643 \\
\hline 50 & $\mathrm{CCOC}$ & C6 & C9 & $\mathrm{O} 3$ & $\mathrm{C} 12$ & -142.4469 \\
\hline 51 & $\mathrm{CCOC}$ & $\mathrm{C} 10$ & C9 & $\mathrm{O} 3$ & $\mathrm{C} 12$ & -16.6523 \\
\hline 52 & $\mathrm{HCOC}$ & $\mathrm{H} 10$ & C9 & $\mathrm{O} 3$ & $\mathrm{C} 12$ & 100.4924 \\
\hline 53 & CCCC & C9 & $\mathrm{C} 10$ & $\mathrm{C} 11$ & $\mathrm{C} 12$ & -26.1870 \\
\hline 54 & $\mathrm{CCCC}$ & C9 & $\mathrm{C} 10$ & C11 & $\mathrm{C} 14$ & -149.4114 \\
\hline 55 & $\mathrm{CCCH}$ & C9 & $\mathrm{C} 10$ & C11 & $\mathrm{H} 12$ & 89.2484 \\
\hline 56 & $\mathrm{CCCC}$ & C13 & $\mathrm{C} 10$ & C11 & $\mathrm{C} 12$ & 96.4882 \\
\hline 57 & $\mathrm{CCCC}$ & $\mathrm{C} 13$ & $\mathrm{C} 10$ & C11 & $\mathrm{C} 14$ & -26.7362 \\
\hline 58 & $\mathrm{CCCH}$ & $\mathrm{C} 13$ & $\mathrm{C} 10$ & $\mathrm{C} 11$ & H12 & -148.0763 \\
\hline 59 & $\mathrm{HCCC}$ & H11 & $\mathrm{C} 10$ & C11 & $\mathrm{C} 12$ & -142.1428 \\
\hline 60 & $\mathrm{HCCC}$ & H11 & $\mathrm{C} 10$ & $\mathrm{C} 11$ & $\mathrm{C} 14$ & 94.6328 \\
\hline 61 & $\mathrm{HCCH}$ & H11 & $\mathrm{C} 10$ & $\mathrm{C} 11$ & H12 & -26.7074 \\
\hline 62 & $\mathrm{CCCH}$ & C9 & $\mathrm{C} 10$ & $\mathrm{C} 13$ & H14 & -60.6837 \\
\hline 63 & $\mathrm{CCCH}$ & C9 & $\mathrm{C} 10$ & $\mathrm{C} 13$ & H15 & 59.0139 \\
\hline 64 & $\mathrm{CCCH}$ & C9 & $\mathrm{C} 10$ & $\mathrm{C} 13$ & H16 & 59.0139 \\
\hline 65 & $\mathrm{CCCH}$ & $\mathrm{C} 11$ & $\mathrm{C} 10$ & $\mathrm{C} 13$ & H14 & -177.1356 \\
\hline 66 & $\mathrm{CCCH}$ & $\mathrm{C} 11$ & $\mathrm{C} 10$ & $\mathrm{C} 13$ & $\mathrm{H} 15$ & -57.4379 \\
\hline 67 & $\mathrm{CCCH}$ & $\mathrm{C} 11$ & $\mathrm{C} 10$ & $\mathrm{C} 13$ & H16 & -57.4379 \\
\hline 68 & $\mathrm{HCCH}$ & H11 & $\mathrm{C} 10$ & C13 & H14 & 60.3525 \\
\hline 69 & $\mathrm{HCCH}$ & H11 & $\mathrm{C} 10$ & $\mathrm{C} 13$ & $\mathrm{H} 15$ & -59.2647 \\
\hline 70 & $\mathrm{HCCH}$ & H11 & $\mathrm{C} 10$ & C13 & H16 & -179.9499 \\
\hline 71 & $\mathrm{CCCO}$ & $\mathrm{C} 10$ & C11 & $\mathrm{C} 12$ & $\mathrm{O} 3$ & 17.9398 \\
\hline 72 & $\mathrm{CCCC}$ & $\mathrm{C} 10$ & C11 & $\mathrm{C} 12$ & $\mathrm{C} 15$ & 139.9844 \\
\hline 73 & $\mathrm{CCCH}$ & $\mathrm{C} 10$ & C11 & $\mathrm{C} 12$ & H13 & -96.3406 \\
\hline 74 & $\mathrm{CCCO}$ & $\mathrm{C} 14$ & C11 & $\mathrm{C} 12$ & $\mathrm{O} 3$ & 143.7871 \\
\hline 75 & $\mathrm{CCCC}$ & C14 & C11 & $\mathrm{C} 12$ & $\mathrm{C} 15$ & -94.1684 \\
\hline 76 & $\mathrm{CCCH}$ & $\mathrm{C} 14$ & $\mathrm{C} 11$ & $\mathrm{C} 12$ & H13 & 29.5067 \\
\hline 77 & $\mathrm{HCCO}$ & H12 & $\mathrm{C} 11$ & C12 & $\mathrm{O} 3$ & -96.9499 \\
\hline 78 & $\mathrm{HCCC}$ & H12 & C11 & $\mathrm{C} 12$ & $\mathrm{C} 15$ & 25.0946 \\
\hline 79 & $\mathrm{HCCH}$ & $\mathrm{H} 12$ & $\mathrm{C} 11$ & $\mathrm{C} 12$ & H13 & 148.7697 \\
\hline 80 & $\mathrm{CCCH}$ & $\mathrm{C} 10$ & C11 & $\mathrm{C} 14$ & H17 & 148.7697 \\
\hline 81 & $\mathrm{CCCH}$ & $\mathrm{C} 10$ & $\mathrm{C} 11$ & $\mathrm{C} 14$ & H18 & 112.3192 \\
\hline
\end{tabular}



DOI: 10.5281/zenodo.3698202

\begin{tabular}{|c|c|c|c|c|c|c|}
\hline 82 & $\mathrm{CCCH}$ & $\mathrm{C} 10$ & C11 & C14 & H19 & -115.3737 \\
\hline 83 & $\mathrm{CCCH}$ & $\mathrm{C} 12$ & C11 & $\mathrm{C} 14$ & H17 & -118.8964 \\
\hline 84 & $\mathrm{CCCH}$ & $\mathrm{C} 12$ & $\mathrm{C} 11$ & C14 & $\mathrm{H} 18$ & -6.1431 \\
\hline 85 & $\mathrm{CCCH}$ & $\mathrm{C} 12$ & C11 & C14 & H19 & 125.7299 \\
\hline 86 & $\mathrm{HCCH}$ & H12 & C11 & C14 & H17 & 121.3630 \\
\hline 87 & $\mathrm{HCCH}$ & H12 & C11 & C14 & H18 & -126.3233 \\
\hline 88 & $\mathrm{HCCH}$ & H12 & C11 & C14 & H19 & 5.9893 \\
\hline 89 & CCOC & $\mathrm{C} 11$ & $\mathrm{C} 12$ & $\mathrm{O} 3$ & C9 & -0.9488 \\
\hline 90 & $\mathrm{CCOC}$ & C15 & C12 & $\mathrm{O} 3$ & C9 & -123.3223 \\
\hline 91 & HCOC & H13 & C12 & $\mathrm{O} 3$ & C9 & 118.0075 \\
\hline 92 & CCCC & C11 & C12 & $\mathrm{C} 15$ & C16 & -78.6900 \\
\hline 93 & CCCC & $\mathrm{C} 11$ & C12 & $\mathrm{C} 15$ & $\mathrm{C} 20$ & 100.2399 \\
\hline 94 & OCCC & $\mathrm{O} 3$ & $\mathrm{C} 12$ & $\mathrm{C} 15$ & $\mathrm{C} 16$ & 41.9977 \\
\hline 95 & OCCC & $\mathrm{O} 3$ & $\mathrm{C} 12$ & $\mathrm{C} 15$ & $\mathrm{C} 20$ & -139.0723 \\
\hline 96 & $\mathrm{HCCC}$ & H13 & $\mathrm{C} 12$ & $\mathrm{C} 15$ & C16 & 156.9475 \\
\hline 97 & HCCC & H13 & C12 & $\mathrm{C} 15$ & $\mathrm{C} 20$ & -24.1226 \\
\hline 98 & CCCC & $\mathrm{C} 12$ & $\mathrm{C} 15$ & C16 & C17 & 179.2402 \\
\hline 99 & $\mathrm{CCCH}$ & C12 & C15 & C16 & $\mathrm{H} 20$ & -1.3959 \\
\hline 100 & CCCC & $\mathrm{C} 20$ & C15 & C16 & $\mathrm{C} 17$ & 0.3444 \\
\hline 101 & $\mathrm{CCCH}$ & $\mathrm{C} 20$ & $\mathrm{C} 15$ & $\mathrm{C} 16$ & $\mathrm{H} 20$ & 179.7083 \\
\hline 102 & CCCC & C12 & C15 & $\mathrm{C} 20$ & C19 & -179.0204 \\
\hline 103 & $\mathrm{CCCH}$ & $\mathrm{C} 12$ & $\mathrm{C} 16$ & $\mathrm{C} 20$ & $\mathrm{H} 22$ & 0.8634 \\
\hline 104 & $\mathrm{CCCC}$ & $\mathrm{C} 16$ & $\mathrm{C} 16$ & $\mathrm{C} 20$ & $\mathrm{C} 19$ & -0.1033 \\
\hline 105 & $\mathrm{CCCH}$ & C16 & $\mathrm{C} 16$ & $\mathrm{C} 20$ & $\mathrm{H} 22$ & 179.7805 \\
\hline 106 & $\mathrm{CCCC}$ & $\mathrm{C} 15$ & $\mathrm{C} 16$ & $\mathrm{C} 17$ & $\mathrm{C} 18$ & -0.3480 \\
\hline 107 & $\mathrm{CCCO}$ & $\mathrm{C} 15$ & $\mathrm{C} 16$ & $\mathrm{C} 17$ & $\mathrm{O} 4$ & 179.8891 \\
\hline 108 & HCCC & $\mathrm{H} 20$ & $\mathrm{C} 16$ & $\mathrm{C} 17$ & $\mathrm{C} 18$ & -179.7052 \\
\hline 109 & $\mathrm{HCCO}$ & $\mathrm{H} 20$ & $\mathrm{C} 16$ & $\mathrm{C} 17$ & $\mathrm{O} 4$ & 0.5319 \\
\hline 110 & CCCC & C16 & C17 & $\mathrm{C} 18$ & C19 & 0.1087 \\
\hline 111 & $\mathrm{CCCO}$ & C16 & C17 & $\mathrm{C} 18$ & O5 & -179.8470 \\
\hline 112 & OCCC & O4 & $\mathrm{C} 17$ & C18 & C19 & 179.9106 \\
\hline 113 & OCCO & $\mathrm{O} 4$ & $\mathrm{C} 17$ & $\mathrm{C} 18$ & O5 & -0.0450 \\
\hline 114 & CCOC & C16 & C17 & $\mathrm{O} 4$ & $\mathrm{C} 21$ & -179.8896 \\
\hline 115 & CCOC & $\mathrm{C} 18$ & $\mathrm{C} 17$ & $\mathrm{O} 4$ & $\mathrm{C} 21$ & 0.3233 \\
\hline 116 & CCCC & C17 & C18 & C19 & $\mathrm{C} 20$ & 0.1452 \\
\hline 117 & $\mathrm{CCCH}$ & $\mathrm{C} 17$ & $\mathrm{C} 18$ & $\mathrm{C} 19$ & $\mathrm{H} 21$ & 179.9260 \\
\hline 118 & OCCC & O5 & $\mathrm{C} 18$ & C19 & $\mathrm{C} 20$ & -179.9080 \\
\hline 119 & $\mathrm{OCCH}$ & $\mathrm{O} 5$ & $\mathrm{C} 18$ & $\mathrm{C} 19$ & $\mathrm{H} 21$ & -0.1272 \\
\hline 120 & $\mathrm{CCOC}$ & $\mathrm{C} 17$ & $\mathrm{C} 18$ & O5 & $\mathrm{C} 21$ & -0.2534 \\
\hline 121 & $\mathrm{CCOC}$ & $\mathrm{C} 19$ & $\mathrm{C} 18$ & $\mathrm{O} 5$ & $\mathrm{C} 21$ & 179.7946 \\
\hline 122 & CCCC & C18 & C19 & $\mathrm{C} 20$ & $\mathrm{C} 15$ & -0.1462 \\
\hline 123 & $\mathrm{CCCH}$ & $\mathrm{C} 18$ & C19 & $\mathrm{C} 20$ & $\mathrm{H} 22$ & 179.9692 \\
\hline 124 & $\mathrm{HCCC}$ & $\mathrm{H} 21$ & $\mathrm{C} 19$ & $\mathrm{C} 20$ & $\mathrm{C} 15$ & -179.9287 \\
\hline 125 & $\mathrm{HCCH}$ & $\mathrm{H} 21$ & $\mathrm{C} 19$ & $\mathrm{C} 20$ & $\mathrm{H} 22$ & 0.1868 \\
\hline
\end{tabular}




\begin{tabular}{|c|c|c|c|c|c|c|}
\hline 126 & COCO & C17 & O4 & C21 & O5 & -0.4796 \\
\hline 127 & COCH & C17 & O4 & C21 & H23 & -119.3612 \\
\hline 128 & COCH & C17 & O4 & C21 & H24 & 118.4501 \\
\hline 129 & OCOC & O4 & C21 & O5 & C18 & 0.4531 \\
\hline 130 & HCOC & H23 & C21 & O5 & C18 & 119.3183 \\
\hline 131 & HCOC & H24 & C21 & O5 & C18 & -118.4820 \\
\hline
\end{tabular}

\section{Acknowledgements}

The present work was partially funded by $\mathrm{CNPq}$ - National Council for Scientific and Technological Development and CAPES - Brazilian Federal Agency for Support and Evaluation of Postgraduate Education of the Brazilian Ministry of Education.

\section{References}

[1] N. Grandisin et al., "Antileishmanial Activity and Structure-Activity Relationship of Triazolic Compounds Derived from the Neolignans Grandisin, Veraguensin, and Machilin G," no. Cl, 2016.

[2] T. B. Cassamale, E. C. Costa, D. B. Carvalho, and N. S. Cassemiro, "Tatiana B. Cassamale," vol. 27, no. 7, pp. 1217-1228, 2016.

[3] G. E. Miana, S. R. Ribone, D. M. A. Vera, S. Manuel, M. R. Mazzieri, and M. A. Quevedo, "European Journal of Medicinal Chemistry Design, synthesis and molecular docking studies of novel N -arylsulfonyl-benzimidazoles with anti Trypanosoma cruzi activity," vol. 165, pp. 1-10, 2019.

[4] "Universidade federal da bahia faculdade de medicina fundação oswaldo cruz," 2017.

[5] M. M. Marinho et al., "Molecular Fractionation With Conjugate Caps Study Of The Interaction Of The Anacardic Acid With The Active Site Of Trypanosoma Cruzi Gapdh Enzyme: A Quantum Investigation," Asian J Pharm Clin Res, vol. 12, no. 12, 2019.

[6] F. F. Ribeiro, F. J. B. M. Junior, M. S. da Silva, M. T. ulliu. Scotti, and L. Scotti, "Computational and Investigative Study of Flavonoids Active Against Typanosoma cruzi and Leishmania spp," Nat. Prod. Commun., 2015.

[7] T. B. Cassamale et al., "Synthesis and Antitrypanosomastid Activity of 1,4-Diaryl-1,2,3-triazole Analogues of Neolignans Veraguensin, Grandisin and Machilin G,” J. Braz. Chem. Soc., 2016.

[8] A. R. das Neves et al., "Effect of isoxazole derivatives of tetrahydrofuran neolignans on intracellular amastigotes of Leishmania (Leishmania) amazonensis: A structure-activity relationship comparative study with triazole-neolignan-based compounds," Chem. Biol. Drug Des., 2019.

[9] O. S. Trefzger et al., "Design, synthesis and antitrypanosomatid activities of 3,5-diaryl-isoxazole analogues based on neolignans veraguensin, grandisin and machilin G," Chem. Biol. Drug Des., 2019.

[10] E. J. Braga, B. T. Corpe, M. M. Marinho, and E. S. Marinho, "Molecular electrostatic potential surface, HOMO-LUMO, and computational analysis of synthetic drug Rilpivirine," Int. J. Sci. Eng. Res., vol. 7, no. 7, pp. 315-319, 2016.

[11] M. Reges, M. M. Marinho, and E. S. Marinho, "Semi-Empirical Study of the Drug Riociguat, an Important Drug for Oral Treatment against Chronic Thromboembolic Pulmonary Hypertension," Int. J. Sci. Eng. Sci., vol. 1, no. 1, pp. 13-17, 2017.

[12] E. S. Marinho and M. M. Marinho, "A DFT study of synthetic drug topiroxostat: MEP, HOMO, LUMO,” Int. J. Sci. Eng. Res., vol. 7, no. July, pp. 1264-1270, 2016. 
[13] J. Silva, A. R. Lima, L. L. Bezerra, M. M. Marinho, and E. S. Marinho, "Bixinoids potentially active against dengue virus: a molecular docking study," JInternational J. Sci. Eng. Res., vol. 8, no. 4, pp. 882-887, 2017.

[14] A. R. Lima, J. Silva, L. L. Bezerra, M. M. Marinho, and E. S. Marinho, "Molecular docking of potential curcuminoids inhibitors of the NS1 protein of dengue virus," Int. J. Sci. Eng. Res., vol. 8, no. 4, 2017.

[15] E. S. M. G. A. Araújo, E. P. Silva, E. P. Sanabio, J. A. Pinheiro, R.R. Castro, R.R. Castro, M.M. Marinho, F. K. S.Lima, "Characterization in Silico of the Structural Parameters of the Antifungal Agent Ketoconazole," Sci. Signpost Publ., 2016.

[16] M. Reges, M. M. Marinho, and E. S. Marinho, "In Silico Characterization of Hypoglycemic Agent Phenformin Using Classical Force Field MMFF94,” Int. J. Recent Res. Rev., vol. XI, no. 2, pp. 3643, 2018.

[17] J. Silva, A. R. Lima, L. L. Bezerra, M. M. Marinho, and E. S. Marinho, "Molecular coupling study between the potential inhibitor of dengue fever, Annatto and Protein E (DENV-4)," Int. J. Sci. Eng. Res. Vol., vol. 8, no. 7, pp. 815-821, 2017.

[18] M. M. Marinho, R. R. Castro, and E. S. Marinho, "Utilização Do Método Semi-Empírico Pm7 Para Caracterização Do Fármaco Atalureno : Homo ,Lumo, Mesp,” Rev. Expressão Católica, vol. 1, no. 1, pp. 177-184, 2016.

[19] Protein Data Bank, "RCSB PDB: Homepage," RCSB PDB, 2019. .

[20] S. Kim et al., "PubChem 2019 update: Improved access to chemical data," Nucleic Acids Res., 2019.

[21] J. Mancuso and R. J. McEachern, "Applications of the PM3 semi-empirical method to the study of triethylenediamine," J. Mol. Graph. Model., 1997.

[22] S. S. Carneiro, M. M. Marinho, and E. S. Marinho, "Electronic / Structural Characterization of Antiparkinsonian Drug Istradefylline : A Semi-Empirical Study,” Int. J. Recent Res. Rev., vol. X, no. 4, pp. 9-14, 2017.

[23] V. M. De Oliveira, M. M. Marinho, and E. S. Marinho, "Semi-Empirical Quantum Characterization of the Drug Selexipag: HOMO and LUMO and Reactivity Descriptors," Int. J. Recent Res. Rev., vol. XII, no. 2, pp. 15-20, 2019.

[24] A. R. Lima, E. M. Marinho, J. Silva, M. M. Marinho, and E. S. Marinho, "Estudo In Silico Do Flavonoide Antitrombótico Ternatina, Presente Nos Capítulos Florais De In Silico Study Of Flavonoid Antithrombotic Ternatin Present In The Flowers Chapters Of Egletes Viscosa Less “ Macela -Da- Terra ,"” Rev. Expressão Católica Saúde, vol. 2, no. 1, 2017.

[25] K. Brak et al., "Nonpeptidic tetrafluorophenoxymethyl ketone Cruzain inhibitors as promising new leads for chagas disease chemotherapy," J. Med. Chem., 2010.

[26] F. Pavão et al., "Structure of Trypanosoma cruzi glycosomal glyceraldehyde-3-phosphate dehydrogenase complexed with chalepin, a natural product inhibitor, at 1.95 A $\AA$ resolution," FEBS Lett., 2002.

[27] A. Saravanamuthu, T. J. Vickers, C. S. Bond, M. R. Peterson, W. N. Hunter, and A. H. Fairlamb, "Two interacting binding sites for quinacrine derivatives in the active site of trypanothione reductase: A template for drug design," J. Biol. Chem., 2004.

[28] F. N. M. Lucio, J. E. da Silva, E. M. Marinho, F. R. D. S. Mendes, M. M. Marinho, and E. S. Marinho, "Methylcytisine Alcaloid Potentially Active Against Dengue Virus: A Molecular Docking Study And Electronic Structural Characterization,” Int. J. Res. -GRANTHAALAYAH, vol. 8, no. January, pp. 221-236, 2020.

[29] A. K. Agrahari and C. George Priya Doss, "A Computational Approach to Identify a Potential Alternative Drug With Its Positive Impact Toward PMP22,” J. Cell. Biochem., 2017.

[30] R. Huey, G. M. Morris, and S. Forli, "Using autodock 4 and autodock vina with autodocktools : a tutorial," 2012. 
[31] D. S. BIOVIA et al., "Dassault Systèmes BIOVIA, Discovery Studio Visualizer, v.17.2, San Diego: Dassault Systèmes, 2016. ,” J. Chem. Phys., 2000.

[32] E. F. Pettersen et al., "UCSF Chimera - A visualization system for exploratory research and analysis," J. Comput. Chem., vol. 25, no. 13, pp. 1605-1612, 2004.

[33] A. Arroio, K. M. Honório, and A. B. F. Da Silva, "Propriedades químico-quânticas empregadas em estudos das relações estrutura-atividade," Quim. Nova, vol. 33, no. 3, pp. 694-699, 2010.

[34] B. Nagy and F. Jensen, "Basis Sets in Quantum Chemistry," 2017.

[35] D. Lopes et al., "Characterization of the natural pesticide 6-desoxyclitoriacetal: a quantum study," Int. J. Sci. Eng. Res., 2019.

[36] L. Paes, W. L. Santos, M. M. Marinho, and E. S. Marinho, "Estudo Dft Do Alcaloide Dicentrina: Gap, Homo, Lumo, Mesp E Mulliken," JOIN, no. 1, 2017.

[37] T. Koopmans, "Über die Zuordnung von Wellenfunktionen und Eigenwerten zu den Einzelnen Elektronen Eines Atoms," Physica, 1934.

[38] F. Jensen, "Atomic orbital basis sets," Wiley Interdisciplinary Reviews: Computational Molecular Science. 2013.

[39] F. Jensen, "The optimum contraction of basis sets for calculating spin-spin coupling constants," Theor. Chem. Acc., 2010.

[40] “Cargas Atômicas em Moléculas," Quim. Nova, 1996.

[41] N. Prabavathi, A. Nilufer, and V. Krishnakumar, "Molecular structure, vibrational, UV, NMR, hyperpolarizability, NBO and HOMO-LUMO analysis of Pteridine2,4-dione," Spectrochim. Acta - Part A Mol. Biomol. Spectrosc., 2012.

[42] P. T. Okoli et al., "In Silico Study of Phytochemical Chlorogenic Acid: A Semi- Empirical Quantum Study and Adme," Int. J. Recent Res. Rev., vol. 52, no. 4, pp. 345-357, 2019.

[43] Kotz, Chemistry \& Chemical Reactivity. 2014.

[44] C. Henrique et al., "Characterization of the natural insecticide methylcytisine: An in silico study using classic force field," Int. J. Recent Res. Rev., vol. XII, no. 2, pp. 15-20, 2019.

[45] D. Lopes et al., "In Silico Studies Of Sophoraflavanone G: Quantum Characterization And Admet," Int. J. Res. - GRANTHAALAYAH, vol. 7, no. November, pp. 160-179, 2019.

[46] R. B. de A. E. J. Barreiro, C. R. Rodrigues, M. G. Albuquerque, C. M. R. de Sant'anna, "Molecular Modeling: A Tool for the Rational Planning of Drugs in Medicinal Chemistry," New Chem., vol. 20, p. 1, 1997.

[47] E. J. Barreiro, C. Alberto, and M. Fraga, Química medicinal: as bases moleculares da ação dos fármacos. .

[48] A. R. Lima and E. S. Marinho, "Alicina uma potencial aliada contra a Chikungunya ( CHIKV ): um estudo de docking molecular," An. do XXIII Encontro Iniciac. a Pesqui. -UNIFOR, vol. 3, 2017.

[49] J. C. Kotz, P. M. Treichel, and J. R. Townsend, Chemistry and Chemical Reactivity. 2012.

[50] D. Yusuf, A. M. Davis, G. J. Kleywegt, and S. Schmitt, "An alternative method for the evaluation of docking performance: RSR vs RMSD,” J. Chem. Inf. Model., 2008.

[51] R. A. Costa et al., "CHEMISTRY Studies of NMR, molecular docking, and molecular dynamics simulation of new promising inhibitors of Cruzaine from the parasite Trypanosoma cruzi," Med. Chem. Res., pp. 246-259, 2019.

[52] A. A. De Marchi, S. Castilho, P. Gustavo, B. Nascimento, C. Archanjo, and D. Ponte, "New 3piperonylcoumarins as inhibitors of glycosomal glyceraldehyde-3-phosphate dehydrogenase ( gGAPDH ) from Trypanosoma cruzi," vol. 12, pp. 4823-4833, 2004.

[53] A. Saravanamuthu et al., "Enzyme Catalysis and Regulation: Two Interacting Binding Sites for Quinacrine Derivatives in the Active Site of Trypanothione Reductase: A TEMPLATE FOR DRUG DESIGN Two Interacting Binding Sites for Quinacrine Derivatives in the Active Site of Trypanothione Reductase," 2004. 
[54] V. Screening, T. Reductase, and N. P. Database, "Artigo Triagem Virtual Aplicada na Busca de Inibidores da Tripanotiona Redutase de Trypanosoma cruzi Utilizando a Base de Dados de Produtos Naturais do Semiárido Baiano ( NatProDB ) Virtual Screening applied to search of inhibitors of Trypanosoma cruzi Trypanothione Reductase employing the Natural Products Database from Bahia state ( NatProDB ) Revista Virtual de Química Triagem Virtual Aplicada na Busca de Inibidores da Tripanotiona Redutase de Trypanosoma cruzi Utilizando a Base de Dados de Produtos Naturais do Semiárido Baiano ( NatProDB ) Vinícius G . da Paixão ,* Samuel S . R . Pita," vol. XX, no. Xx, 2016.

[55] S. S. R, S. S. R. Pita, and P. G. Pascutti, "Artigo Alvos Terapêuticos na Doença de Chagas : a Tripanotiona Redutase como Foco Therapeutic $T$ argets in Chagas ' Disease: a Focus on Trypanothione Reductase Resumo Alvos Terapêuticos na Doença de Chagas : a Tripanotiona Redutase como Foco 1 . Panorama Global das Doenças," vol. 3, no. 4, pp. 307-324, 2011.

*Corresponding author.

E-mail address: emmanuel.marinho@uece.br 